\title{
Overview towards improved understanding of the mechanisms leading to heavy precipitation in the western Mediterranean: lessons learned from $\mathrm{HyMeX}$
}

\author{
Samira Khodayar ${ }^{1}$, Silvio Davolio ${ }^{2}$, Paolo Di Girolamo ${ }^{3}$, Cindy Lebeaupin Brossier ${ }^{4}$, Emmanouil Flaounas $^{5}$, \\ Nadia Fourrie $^{4}$, Keun-Ok Lee ${ }^{6,7}$, Didier Ricard ${ }^{4}$, Benoit Vie $^{4}$, Francois Bouttier ${ }^{4}$, Alberto Caldas-Alvarez ${ }^{8}$, and \\ Veronique Ducrocq ${ }^{4}$ \\ ${ }^{1}$ Mediterranean Centre for Environmental Studies (CEAM), Valencia, Spain \\ ${ }^{2}$ National Research Council of Italy, Institute of Atmospheric Sciences and Climate, (CNR-ISAC), Bologna, Italy \\ ${ }^{3}$ Scuola di Ingegneria, Università degli Studi della Basilicata (SI-UNIBAS), Potenza, Italy \\ ${ }^{4}$ CNRM, Université de Toulouse, Météo-France, CNRS, Toulouse, France \\ ${ }^{5}$ Institute of Oceanography, Hellenic Centre for Marine Research (HCMR), Athens, Greece \\ ${ }^{6}$ Laboratoire d'Aérologie, Université de Toulouse, CNRS, UPS, Toulouse, France \\ ${ }^{7}$ Laboratoire de L'Atmosphère et des Cyclones, UMR 8105 (CNRS, Université de La Réunion, \\ Météo-France), Saint Denis, France \\ ${ }^{8}$ Institute of Meteorology and Climate Research (IMK-TRO), Karlsruhe Institute of Technology (KIT), Karlsruhe, Germany
}

Correspondence: Samira Khodayar (khodayar_sam@gva.es)

Received: 26 April 2021 - Discussion started: 29 April 2021

Revised: 6 August 2021 - Accepted: 6 August 2021 - Published: 24 November 2021

\begin{abstract}
Heavy precipitation (HP) constitutes a major meteorological threat in the western Mediterranean (WMed). Every year, recurrent events affect the area with fatal consequences for infrastructure and personal losses. Despite this being a well-known issue widely investigated in the past, open questions still remain. Particularly, the understanding of the underlying mechanisms and the modeling representation of the events must be improved. One of the major goals of the Hydrological Cycle in the Mediterranean Experiment (HyMeX; 2010-2020) has been to advance knowledge on this topic. In this article, we present an overview of the most recent lessons learned from HyMeX towards an improved understanding of the mechanisms leading to HP in the WMed.

The unique network of instruments deployed as well as the use of finer model resolutions and coupled models provided an unprecedented opportunity to validate numerical model simulations, develop improved parameterizations, and design high-resolution ensemble modeling approaches and sophisticated assimilation techniques across scales.
\end{abstract}

All in all, HyMeX, and particularly the science team heavy precipitation, favored the evidencing of theoretical results, the enrichment of our knowledge on the genesis and evolution of convection in a complex topography environment, and the improvement of precipitation forecasts. Illustratively, the intervention of cyclones and warm conveyor belts in the occurrence of heavy precipitation has been pointed out, and the crucial role of the spatiotemporal distribution of atmospheric water vapor for the understanding and accurate forecast of the timing and location of deep convection has been evidenced, as has the complex interaction among processes across scales. The importance of soil and ocean conditions and the interactions among systems were highlighted, and such systems were specifically developed in the framework of HyMeX to improve the realism of weather forecasts. Furthermore, the benefits of cross-disciplinary efforts within HyMeX have been a key asset in bringing our knowledge about heavy precipitation in the Mediterranean region a step forward. 


\section{Introduction and motivation}

A 10-year multidisciplinary program on the Mediterranean water cycle, HyMeX (Hydrological Cycle in the Mediterranean Experiment; Drobinski et al., 2014), has come to an end (2010-2020). With the main goal of advancing scientific knowledge of the Mediterranean water cycle variability and improving process-based and regional climate models, different temporal scales are considered, from the weather scale to the seasonal and interannual scales. Special focus is put on the hydrometeorological extremes and consequent social and economic impacts, as well as the vulnerability and the adaptation capacity of the Mediterranean population under climate change.

The unique character of the Mediterranean basin and surrounding countries resulting from the geographical location, climatic conditions, and topography makes the region prone to extreme phenomena, heavy precipitation and flash floods, and heat waves and drought (e.g., Mariotti, 2010). The region, defined as one of the two main "hot spots" of climate change (Giorgi, 2006; IPCC, 2013), is in a transition area and is therefore very sensitive to global climate change at short and long timescales. An increase in interannual rainfall variability, strong warming and drying, and significant population growth are projected for the coming future. Despite the overall Mediterranean climate drying, under climate change, the intensity of heavy precipitation events (HPEs) is expected to increase (Planton et al., 2016; Jacob et al., 2013; Drobinski et al., 2016; Colmet-Daage et al., 2018; Tramblay and Somot, 2018; Giorgi et al., 2019). In this context, threats posed by the expected increase in the frequency and intensity of events conducive to floods and droughts (Gao et al., 2006; Orlowsky and Seneviratne, 2011) are seen with great concern. Countries surrounding the Mediterranean basin already suffer from problems in relation to water shortages and floods. Food security could also become an issue (Nelson et al., 2010).

HPEs and the associated flash floods are the most dangerous meteorological hazards affecting the Mediterranean countries in terms of mortality, and hundreds of millions of Euros in damage are reported every year (Llasat et al., 2010, 2013; Doocy et al., 2013). The Mediterranean basin and the surrounding mountainous coastal regions are often affected by these phenomena regularly in the autumn period. The Mediterranean Sea, acting as a heat and moisture source, and the steep orography, triggering convection, are key aspects determining the occurrence of heavy precipitation in the region which, is mainly of a convective nature (Funatsu et al., 2008; Dayan et al., 2015). Rainfall accumulation greater than $100-150 \mathrm{~mm}$ may be expected in less than a day or even just a few hours resulting mostly from quasi-stationary mesoscale convective systems (MCSs; Lee et al., 2018, 2017, 2016; Duffourg et al., 2018; Buzzi et al., 2014). Such rainfall accumulation is favored by a slowly evolving synoptic situation, characterized by an upper-level trough and consequent cyclogenesis that induces advection of warm and moist air from the Mediterranean Sea (Duffourg and Ducrocq, 2011) to the coasts through marine low-level jets (Homar et al., 1999; Jansa et al., 2001; Nuissier et al., 2011; Ricard et al., 2012; Khodayar et al., 2016b). Strong wind with high sea surface temperature (SST) governs evaporation, which moistens and warms the lowest levels of the atmosphere, thus increasing instability and finally often enhancing the convection intensity (Xie et al., 2005; Lebeaupin et al., 2006; Stocchi and Davolio, 2017; Rainaud et al., 2017; Senatore et al., 2020a). Low-level convergence over the sea, cold pools beneath the convective systems, or topographic lifting when encountering the coastal mountains trigger deep convection, forcing the lift of the conditionally unstable low-level flow. The synoptic-scale situations associated with these episodes are generally well known and well represented in numerical weather prediction (NWP) model simulations. Nevertheless, in the last few years, additional knowledge has been gained in the field. Vries (2020) presented for the first time a global and systematic climatological analysis of Rossby wave breaking (RWB), intense moisture transport, and their linkage to extreme precipitation events (EPEs), with the findings of this study contributing to an improved understanding of the atmospheric processes that lead to EPEs. Mastrantonas et al. (2021) demonstrated that a clustering combination of sea level pressure (SLP) and geopotential height at $500 \mathrm{hPa}$ (Z500) increases the conditional probability of EPEs by more than a factor of 3 , which could be critical for extended-range forecasts. Grazzini et al. (2021) further investigated the relation between EPEs and Rossby wave packets (RWPs), showing the evolution and properties of precursor RWPs to be key for the categorization of EPEs. Despite the improved understanding, the accuracy of forecasts is still insufficient to adequately assess the timing, location, and intensity of rainfall and flash flooding in certain situations, which is a key step towards prevention and mitigation. This is mostly in relation to (a) model limitations in terms of predictability of smallscale processes (e.g., convection, turbulence) and feedbacks (e.g., soil, atmosphere, ocean) as well as their nonlinear interaction across scales, (b) lack of knowledge regarding underlying mechanisms, and (c) absence of adequate observations to help us advance our understanding and improve model capabilities.

This issue is one of the main objectives of the HyMeX international program and of its associated first special observation period (SOP1; Ducrocq et al., 2014; Jansa et al., 2014; Ferreti et al., 2014) from 5 September to 6 November 2012, which was dedicated to heavy precipitation and flash flooding. Because of the large number of instruments deployed, the unprecedented high spatial-temporal coverage achieved, and the quality of the derived observations, SOP1 has offered a unique opportunity to improve understanding and advance documentation of high-impact weather events. This is in addition to the significant progress achieved in the last decade through the development of convection-permitting 
models, the benefits of which have been sufficiently demonstrated (Richard et al., 2007; Fosser et al., 2014, Prein et al., 2015; Clark et al, 2016, among others), and they are currently widely used by the scientific community.

The major goal of this article is to present an overview of some of the recent years' main achievements towards better understanding of the mechanisms leading to heavy precipitation in the WMed in the framework of the HyMeX international program. Advances regarding improved understanding of the mechanisms governing the initiation and intensification of precipitating systems producing large amounts of rainfall are thoroughly discussed in terms of in situ observations and high-resolution modeling systems, as well as the synergetic use of both to help us bridge knowledge gaps. An intensive observation period, IOP16, which took place during SOP1, is taken as a paradigm to illustrate some of the main HyMeX results in the field of heavy precipitation.

This paper is structured as follows: in Sect. 2 we describe the general conditions leading to HP during the SOP1 period, the state-of-the-art observational networks deployed at this time, and the modeling strategy developed. Additionally, IOP16, which has been used throughout the paper to illustrate some of the results, is presented. In Sect. 3, the main advances regarding HP understanding and modeling are presented, including the large-scale dynamics, advances in moist process understanding, low-level dynamics, the impacts of the land and sea surfaces, and microphysics. Section 4 is devoted to the examination of the improvements in the multiscale modeling of HP, and in Sect. 5 some conclusions and recommendations are summarized.

\section{Heavy precipitation during the HyMeX SOP1 period}

The SOP1 campaign took place in 2012 from 5 September to 6 November, when the probability of HPE occurrence in the northwestern Mediterranean is the highest. About $30 \%$ of the days in this period indeed experienced rainfall accumulation over $100 \mathrm{~mm}$ somewhere in the investigation domain. A total of 20 intensive observation periods (IOPs) were launched during the campaign, most of them occurring in the period after mid-October to the end of SOP1 (Ducrocq et al., 2014). This agrees with the monthly precipitation totals being close to the climatological values in September but well above in October (Khodayar et al., 2016b). Most IOPs did not affect a single site but encompassed several regions of the northwestern Mediterranean. The most affected sites were CévennesVivarais (CV), including the Massif Central and the southern French Alps, and the Liguria-Tuscany (LT) region in Italy.

\subsection{State-of-the-art observational capabilities and modeling activities}

More than 200 research instruments were deployed over the WMed Sea and surrounding countries, namely Spain,
France, and Italy, to ensure close observation of the precipitating systems and a fine-scale survey of the upstream meteorological conditions over the Mediterranean. Ducrocq et al. (2014) provides $=$ a comprehensive description of the observing systems deployed during SOP1. Furthermore, this unique network of instruments provided an unprecedented opportunity to validate NWP model simulations more accurately, to develop novel data assimilation techniques, and to improve model parameterizations with the purpose of better predicting the evolution of the environment across scales.

\subsubsection{Ground-based, airborne, and seaborne observations}

One unique aspect of HyMeX SOP1 was represented by the availability of a large ensemble of ground-based and airborne instruments covering a major portion of the WMed and its surrounding coastal regions in France, Italy, and Spain. The observational domain of HyMeX SOP1 was defined to include the area with the highest occurrence of HPEs and within the ranges of aircraft flight endurance. Within this large domain, five measurement sites including advanced research instruments were established, i.e., the Cévennes-Vivarais (CV) and the Corsica (CO) sites, the central Italy (CI) and northeastern Italy (NEI) sites, and the Spanish Balearic Islands (BA) site including Menorca and Mallorca (Ducrocq et al., 2014). Most sites were equipped with soil moisture sensors, turbulence or energy balance stations, microwave radiometers, lidars, radars (cloud, precipitation, and/or wind), and radiosonde launching facilities, in addition to the operational meteorological and hydrological ground networks covering the entire SOP1 domain. Thus, an unprecedented dense network of rain gauges was available over France, Italy, and Spain, with a density of about one hourly rain gauge per $180 \mathrm{~km}^{2}$. This network operated in combination with a radar network including a variety of Sband, C-band Doppler (two of them being polarimetric), and $\mathrm{X}$-band radars (one of them being polarimetric). A similarly dense network of Global Positioning System (GPS) stations was also established, with stations covering the northwestern Mediterranean basin and including measurements from 25 European, national, and regional GPS networks (Bock et al., 2016).

Three aircraft participated in the field campaign: the French ATR42, the French Falcon 20 (operated by SAFIRE Service des Avions Français Instrumentés pour la Recherche en Environnement), and the German Do128 (Corsmeier et al., 2001). The ATR42 involvement was primarily aimed to characterize the origin and transport pattern of water vapor and aerosol in pre-convective conditions and their link with heavy precipitating systems. Its main payload was the airborne dial LEANDRE 2, capable of profiling water vapor mixing ratio above or beneath the aircraft. The F20 aircraft primary mission was the characterization of the microphysical and kinematic processes taking place within convec- 
tive precipitating systems, with this objective being pursued based on the use of advanced microphysical in situ probes and the $95 \mathrm{GHz}$ Doppler cloud radar RASTA (Radar Aéroporté et Sol de Télédétection des propriétés nuAgeuses; Protat et al., 2009). Furthermore, the German Do128 research aircraft was equipped with fast sensors to measure turbulent fluxes, water vapor inlet, and stable water isotope measurements (Sodemann et al., 2017) with the primary goal of monitoring upstream low-level conditions before and during HPEs and investigating the orographic and thermal impact of the island on the initiation and evolution of diurnal convective activity.

During HyMeX SOP1, boundary layer pressurized balloons (BLPBs) were also launched from Menorca, flying at a nearly constant height (Doerenbecher et al., 2016) and providing Lagrangian trajectories of specific humidity, temperature, pressure, and horizontal wind.

Two ground-based Raman lidars were involved, namely the system BASIL (Di Girolamo et al., 2009) deployed in Candillargues (southern France) and the system WALI (Water vapor Aerosol Raman LIdar; Chazette et al., 2016) deployed in Ciutadella (Menorca, Balearic Islands). Both systems provided long-term records of high-resolution and accurate humidity measurements in both daytime and nighttime throughout the duration of HyMeX SOP1.

At sea, several platforms were deployed to monitor the ocean upper layer and the exchanges with the atmosphere (Ducrocq et al., 2014; Lebeaupin Brossier et al., 2014; Rainaud et al., 2015). Two Météo-France moored buoys, LION $\left(4.7^{\circ} \mathrm{E}-42.1^{\circ} \mathrm{N}\right)$ and AZUR $\left(7.8^{\circ} \mathrm{E}-43.4^{\circ} \mathrm{N}\right)$, routinely provide the $2 \mathrm{~m}$ temperature, humidity, mean sea level pressure and sea surface parameters (SST, wave height, and period), and $10 \mathrm{~m}$ wind speed, direction, and gust intensity. They were equipped with additional sensors for $\mathrm{HyMeX}$ with radiative flux measurements, rain gauges, a thermosalinograph measuring the near-surface temperature and salinity, and a thermobathymetric chain giving the ocean temperature between 5 and $250 \mathrm{~m}$ depths. During SOP1, up to five gliders monitored the area simultaneously, providing 0 $1000 \mathrm{~m}$ profiles along repeated transects. Observations from ships include conductivity-temperature-depth (CTD) profiles (up to a depth of $200 \mathrm{~m}$ ) and radiosoundings from the Le Provence sent into the Gulf of Lion for three IOPs (IOP7, IOP12, and IOP16). Finally, the freighter Marfret Niolon that regularly linked Marseille (France) with Algiers (Algeria) was equipped for HyMeX with the SEOS (Sea Embedded Observation System; https://doi.org/10.6096/MISTRALSHYMEX.748), measuring air temperature, relative humidity, pressure, wind, and SST. Another sensor provided measurements of sea temperature at a depth of almost $3 \mathrm{~m}$ using a high-quality temperature probe (TRANSMED data: https://doi.org/10.6096/MISTRALSHYMEX.973) backed by a thermosalinograph that also provided in situ salinity.

\subsubsection{HyMeX modeling strategy}

Despite significant efforts to improve the skill of forecasts, the forecasting accuracy has proven to still be insufficient in terms of the amount, timing, and location of heavy precipitation. The design of the HyMeX modeling strategy considered three key issues relevant to reduce modeling uncertainty: (a) to be consistent with the observation strategy; (b) to integrate numerical models of the atmosphere, ocean, and land; and (c) to include models of the climate system to cover all scales of time and space. Moreover, through the refinement of model grids and the development of convection-permitting NWP systems and regional climate models (RCMs), significant progress has been made to improve simulations of HPEs, to advance knowledge of the relevant processes and their interactions across scales, and to reduce the large uncertainties in future evolution under climate change. The use of finer-scale and coupled models representing atmosphereocean-land systems and their interactions more accurately and/or the detailed validation using the SOP1 measurements allowed the development of improved parameterizations of physical processes, the design of high-resolution ensemble modeling approaches with a greater number of ensemble members, and a more sophisticated and efficient use of observations for assimilation purposes.

Profiting from these efforts, the HyMeX community has made relevant advances in process knowledge and prediction of heavy precipitation. Some of these advances are discussed and illustrated in the coming sections using IOP16, which is introduced in the following.

\subsection{Illustrative case: IOP16}

IOP16 is a well-documented and widely investigated event observed in the period 25-29 October 2012 over the WMed region. IOP16 was one of the best-equipped observational periods in terms of instrumental coverage during HyMeX SOP1 (Fig. 1). Most ground-based and airborne instrumentation was successfully operational and provided high-quality data, with almost all the on-demand SOP1 instruments involved. Benefiting from this large observational dataset, an extensive number of modeling activities focused on IOP16, with the purpose of investigating different issues related to the occurrence of heavy precipitation, such as the impact of the turbulence representation on the sensitivity of the simulated convective systems (Martinet et al., 2017), the underlying mechanisms of offshore deep convection initiation and maintenance (Duffourg et al., 2016), some assimilation or pre-assimilation experiments (Borderies et al., 2019a), the impact of fine-scale air-sea interactions and coupled processes on heavy precipitation (Rainaud et al., 2017), and novel large eddy simulation (LES) of an HPE (Nuissier et al., 2020).

This event was associated with a propagating cyclone and was observed in two dedicated periods: (a) IOP16a (25- 
26 October), characterized by heavy precipitation over $\mathrm{CV}$ and LT, when several quasi-stationary MCSs developed, two of them over the sea, with subsequent heavy precipitation over the French and Italian coasts on 26 October 2012; and (b) IOP16b (27-29 October) characterized by heavy precipitation over the $\mathrm{CI}$, NEI, and $\mathrm{CO}$ regions.

IOP16a was driven by the presence of a cyclone moving from the easternmost Atlantic to the Pyrenees, followed in phase by a cut-off low, associated with upper-level highpotential vorticity values. In the lower troposphere, the cyclone provoked southwesterly advection of moist and warm air above $20^{\circ} \mathrm{C}$. On the morning of 26 October the cyclone was centered over the Pyrenees, forming a convergence line between the southerly flow and the southwesterly colder winds, while over the Tyrrhenian Sea a southerly moist and warm flow from Tunisia to the Gulf of Genoa established (Fourrié et al., 2015). During the night from 25 to 26 October and on the following day, several MCSs formed under the influence of the cyclone and within its "comma-shaped" cloud coverage. Such cloud coverage is typically found in midlatitude storms and owes its shape to warm conveyor belts (WCBs; Eckhardt et al., 2004; Madonna et al., 2014), i.e., the airstreams that ascend slantwise over the cyclone warm front. All MCSs showed a quasi-stationary behavior, forming first over the sea between the eastern Spanish coast and the Balearic Islands (Duffourg et al., 2016) and afterwards over the Gulf of Lion where they induced large amounts of precipitation over the sea during morning hours.

The first MCS split in two. One system (MCS1a) moved towards the southeast of the Massif Central but progressively decayed, producing just orographic rainfall; the second (MCS1b) strengthened and caused a large precipitation accumulation over the Var region during the afternoon of nearly $150 \mathrm{~mm}$ in $24 \mathrm{~h}$, causing two fatalities in the city of Toulon. A third MCS initiated at about 06:00 UTC on 26 October on the Italian coast of Liguria. The MCS development also occurred offshore of Sardinia and Corsica and reached central Italy during the evening on 26 October, leading to $250 \mathrm{~mm}$ daily precipitation on this day over LiguriaTuscany, with local flash flooding. On the same day, over the Cévennes-Vivarais region, daily precipitation reached $170 \mathrm{~mm}$.

During the second period of 27-28 October 2012, the cyclone center reached the lowest pressure of $985 \mathrm{hPa}$ over the Alps (Fig. 2) associated with a clear trough in the upper troposphere, provoking severe northwesterly-northerly winds advecting cold and dry air over the WMed Sea and inducing large evaporation as well as ocean cooling and mixing (Lebeaupin Brossier et al., 2014; Rainaud et al., 2015, 2017; Seyfried et al., 2019). The relationship between cyclone dynamics and heavy rainfall during IOP16 is discussed in detail by Flaounas et al. (2016).

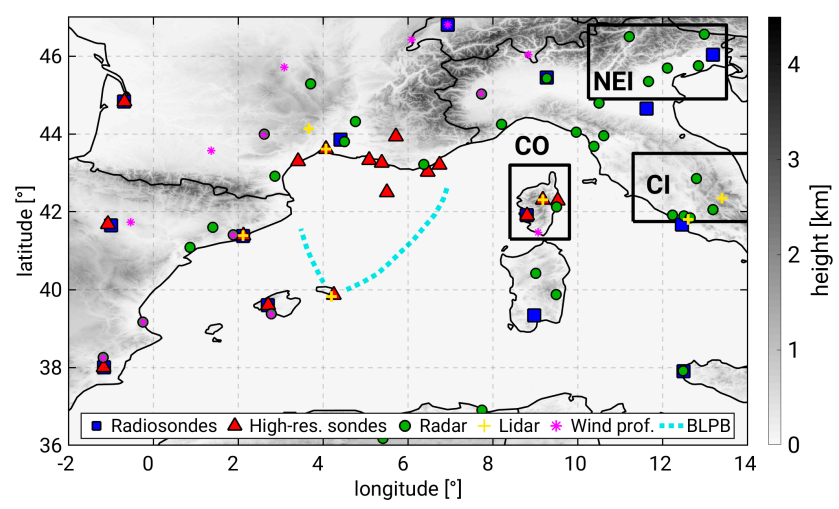

Figure 1. Location of selected experimental setup during IOP16 on 25-28 October 2012, including radiosondes and high-resolution sondes, radar, lidar, wind profilers, and boundary layer pressurized balloons (BLPBs). The position of the GPS receivers can be found in Fig. 3d. The locations of the CO, NEI, and CI subdomains are indicated with black boxes.

\section{Towards improved understanding of the mechanisms leading to heavy precipitation in the western Mediterranean}

\subsection{Large-scale dynamics and HPE occurrence}

Mediterranean cyclogenesis is typically preceded by the intrusion of upper-tropospheric systems such as troughs and cut-off lows. Such systems are typically shown to be direct results of Rossby wave breaking over the Atlantic Ocean related to high-potential vorticity values that trigger cyclogenesis in the Mediterranean due to baroclinic instability (Grams et al., 2011; Raveh-Rubin and Flaounas, 2017). Therefore, most intense Mediterranean cyclones are baroclinic systems with frontal structures and associated airstreams such as dry air intrusions and WCBs (Ziv et al., 2009; Flaounas et al., 2015a). In particular, WCBs are associated with stratiform, but also with convective, rainfall due to embedded convection within their large-scale ascent branch (Flaounas et al., 2018; Oertel et al., 2019). Such is the case of IOP16, during which WCBs and deep convection coexisted to contribute large amounts of rainfall over the western Mediterranean (Fig. 2).

Several past studies showed that HP in the Mediterranean basin is intertwined with the occurrence of cyclones. Scheffknecht et al. (2017) showed that cyclones are present for all HPEs over the island of Corsica when examining the climatology in the period 1985-2015. Embedded deep convection and WCBs are responsible for the majority of total regional precipitation and its extremes (Jansa et al., 2001; Hawcroft et al., 2012; Pfahl et al., 2014; Galanaki et al., 2016; RavehRubin and Wernli, 2015). As an example of cyclone contribution to regional rainfall, Flaounas et al. (2018) showed that the 250 most intense systems of the period 2005-2015 were responsible for up to a third of the total 11-year precipitation, 

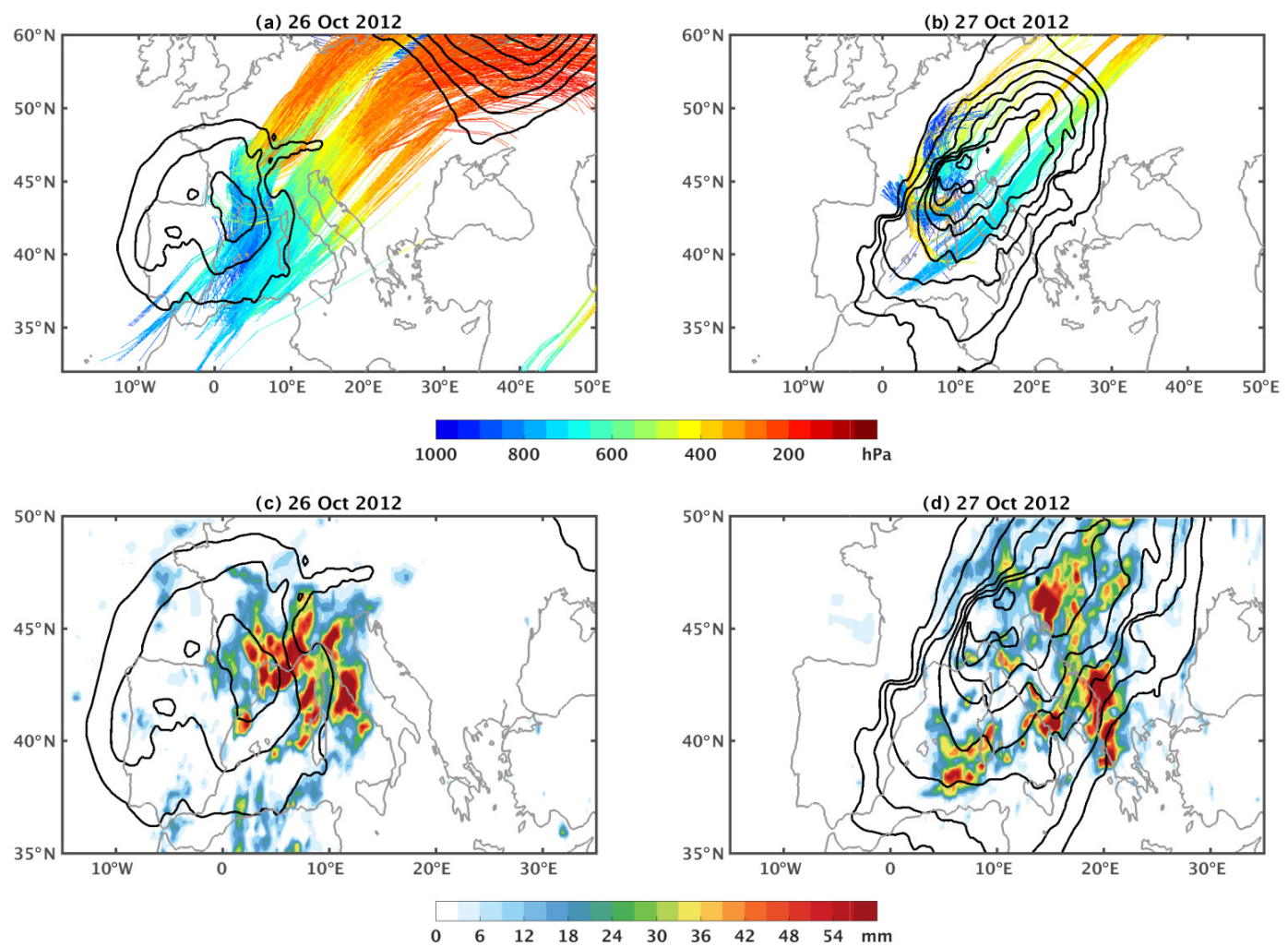

Figure 2. (a) Sea level pressure (black contours every $3 \mathrm{hPa}$; outer contour is set at $1005 \mathrm{hPa}$ ). Colored lines show the pressure level of the WCB air masses related to the cyclone. WCBs are calculated using the ECMWF analyses and correspond to air mass trajectories that present an ascent of more than $500 \mathrm{hPa}$ within $48 \mathrm{~h}$. In panel (a), we show the $48 \mathrm{~h}$ trajectories that correspond to WCBs and where air masses are located close to the cyclone center at 12:00 UTC on 26 October 2012 between 680 and $720 \mathrm{hPa}$, i.e., within the ascending part of the WCBs (line segments in cyan). Panel (b) is as in (a), but for 12:00 UTC on 27 October 2012. (c) Colors show the daily accumulation of precipitation on 26 October 2012 taken from 3B42 of TRMM. Panel (d) is as in (c) for 27 October. Datasets and methods for all panels are detailed in Flaounas et al. (2016).

while climate modeling showed that cyclones contributed $70 \%$ to almost all of the total of rainfall extremes, depending on the area (Flaounas et al., 2015). Such heavy rainfall events are related to water sources from the Mediterranean Sea, but also from the tropical and extratropical Atlantic Ocean. This is due to cyclogenesis being preceded by Rossby wave breaking over the Atlantic that favors the eastward zonal transport of water vapor from oceanic remote areas, rendering water vapor import imperative for the formation of heavy rainfall in the Mediterranean (Duffourg and Ducrocq, 2013; Flaounas et al., 2019).

\subsection{Advances in moist processes understanding}

\subsubsection{Distribution, origin, and transport of the water vapor supply to HPEs}

The relevance of atmospheric water vapor distribution and stratification in the initiation, intensification, and maintenance of HPEs has been extensively demonstrated (e.g., Duffourg et al., 2018; Lee et al., 2018), as has the role of the Mediterranean Sea as a significant heat and moisture source for HPEs in the WMed area (Duffourg and Ducrocq, 2011; Flaounas et al., 2019). The scarcity of water vapor observations at the mesoscale and smaller scales, as well as the model limitations, for example in relation to adequate spatial and temporal resolution and/or an accurate representation of the vertical stratification, has hampered progress in the past. Indeed, our understanding of the variability of water vapor in relation to convection is still far from being complete. Large uncertainties remain regarding the origin, pathways, and timescales of transport of the large amounts of moisture necessary for HPEs in the WMed. Characterization and better understanding of the water vapor supply to HPEs were key aspects of the HyMeX field campaign and subsequent studies. The unprecedented deployment of instruments during SOP1 for the monitoring of water vapor dynamics and the posterior cross-validation studies and synergetic use together with models allowed the many advances achieved in this period, as described in the following.

One of the HyMeX observational highlights is the dense network of GPS stations with over 1000 ground-based receivers, providing a reprocessed dataset specially produced 
for the HyMeX SOP (Bock et al., 2016). The large extent and high-density coverage of the reprocessed GPS network allowed for a consistent representation of large-scale features, as well as smaller spatial and temporal scales in agreement with high-resolution simulations (Bock et al., 2016). Using the reprocessed integrated water vapor (IWV) GPS data, Khodayar et al. (2018) showed that all HPEs within the northwestern Mediterranean form in periods and/or areas characterized by IWV values of the order of 35-45 mm after an increase of $10-20 \mathrm{~mm}$, with the most intense events being those experiencing a more sudden increase (between 6 and $12 \mathrm{~h}$ prior to the event). Bock et al. (2016) demonstrated that regions prone to HPEs in autumn are characterized by high IWV variability up to $8 \mathrm{~kg} \mathrm{~m}^{-2}$.

In addition to the unprecedented (in terms of spatial and temporal coverage) amount of information provided by the post-processed GPS network, modeling studies are helpful for the assessment of potential sources of moisture. Recent advances on this topic showed that evaporation in the western Mediterranean, central Mediterranean, and the North Atlantic as well as advection from the tropical and subtropical Atlantic and Africa constitute the four moisture sources that could explain most of the accumulated precipitation in the WMed (Insua-Costa et al., 2019). The evaporation from the Mediterranean accounts for only about $40 \%(60 \%)$ of the water vapor feeding the deep convection developed over southeastern France when cyclonic (anticyclonic) conditions prevail in the days preceding the event (Duffourg and Ducrocq, 2013). The Atlantic Ocean (Turato et al., 2004; Winschall et al., 2011; Duffourg et al., 2018; Flaounas et al., 2019) and tropical Africa (Krichak et al., 2015; Chazette et al., 2015b; Lee et al., 2016, 2017) have also been suggested as potential sources of moisture for HPEs occurring in the western Mediterranean. The large-scale uplift of an enriched African moisture plume and its role in gradual rain-out of the air parcel over southern Italy during IOP13 were highlighted in a modeling study taking advantage of stable water isotopes by Lee et al. (2019). Backward-trajectory analysis showed that large-scale moisture transport takes place during about 3 to $4 \mathrm{~d}$ in the warm sector of the front, whereas surface evaporation over the Mediterranean occurs in a few hours to $1 \mathrm{~d}$. Associated with extreme precipitation events over Italy, whether convective or orographic, a recent study by Grazzini et al. (2019) confirmed the systematic occurrence of anomalously high values of meridional integrated vapor transport that sometimes occurs in narrow filament-shaped regions of high integrated moisture, called atmospheric rivers (Davolio et al., 2020), such as during the 2011 Liguria floods (Rebora et al., 2013) and the last extreme storms in October 2018 (Giovannini et al., 2021) and October 2020 (Magnusson et al., 2021).

\subsubsection{Assessment of the variability and vertical distribution of the atmospheric water vapor}

The variability and vertical distribution of atmospheric water vapor and their accurate representation in models have been demonstrated to play a key role for the timing, location, and intensification of deep convection (e.g., Khodayar et al., 2018) and thus for the simulation of HPEs. They have been further identified as responsible for inaccuracies in RCMs when compared against convection-permitting NWP models (Khodayar et al., 2016a). To contribute to the characterization of the water vapor variability, the ground-based WALI in the Balearic Islands, the airborne water vapor differential absorption lidar LEANDRE 2 on board the ATR42 aircraft, and boundary layer pressurized balloons (BLPBs; Doerenbecher et al., 2016) were deployed during SOP1. Water vapor mixing ratio (WVMR) profiles were measured with a horizontal resolution of $1 \mathrm{~km}$ (e.g., Flamant et al., 2015; Flaounas et al., 2016; Chazette et al., 2015a, b; Di Girolamo et al., 2017; Duffourg et al., 2016; Lee et al., 2016, 2017). In a multi-instrument and multi-model assessment of atmospheric moisture variability in the northwestern Mediterranean, Chazette et al. (2015b) demonstrated the consistency and self-coherence of these water vapor datasets during SOP1, pointing out the strong need to assimilate highresolution water vapor profiles in the lowest layers such as those from lidar instruments. In a multi-scale observational investigation of atmospheric moisture variability in relation to HPE formation in the same region, Khodayar et al. (2018) profited from the synergetic use of observational datasets, demonstrating that the sampling of spatial inhomogeneities on different scales is crucial for the understanding of the timing and location of deep convection. Furthermore, focusing on the complex island of Corsica during SOP1, multiple observations from the mobile observation platform KITcube (Kalthoff et al., 2013) further demonstrated the benefit of integrated measurement systems (Adler et al., 2015).

The ground-based lidar WALI was useful in capturing the moist and deep boundary layers with updrafts reaching up to $2 \mathrm{~km}$ in pre-convective environments leading to HPEs, contrary to the dry, shallow boundary layers everywhere else (Khodayar et al., 2018). In Chazzete et al. (2015a), the ground-based lidar WALI additionally captured the increasing moistening of the free troposphere up to $5 \mathrm{~km}$ prior to and in relation to MCS formation. Furthermore, the specific humidity observations from BLPBs and aircraft flights captured spatial inhomogeneities in the lower boundary layer up to $4 \mathrm{~g} \mathrm{~kg}^{-1}$ in less than $100 \mathrm{~km}$, which were shown to determine the location of convection initiation (Khodayar et al., 2018).

Figure 3 illustrates for IOP16 the complex moisture flow that fed the convective systems, which was effectively monitored by the variety of water vapor profiling sensors involved in combination with backward- and forward-trajectory analyses from a Lagrangian model (NOAA HYSPLIT Lagrangian 

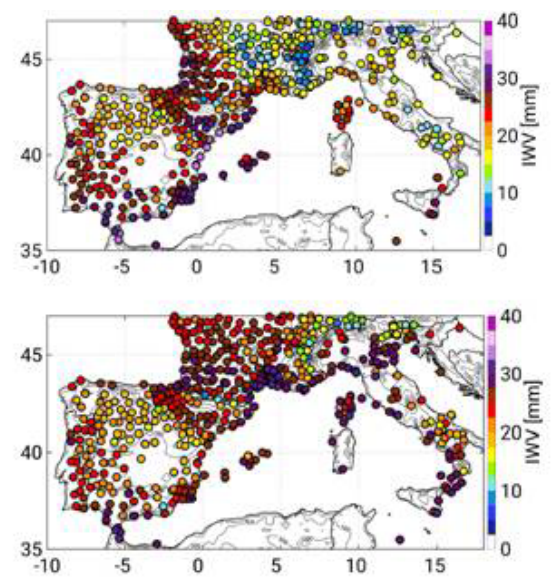

(a)

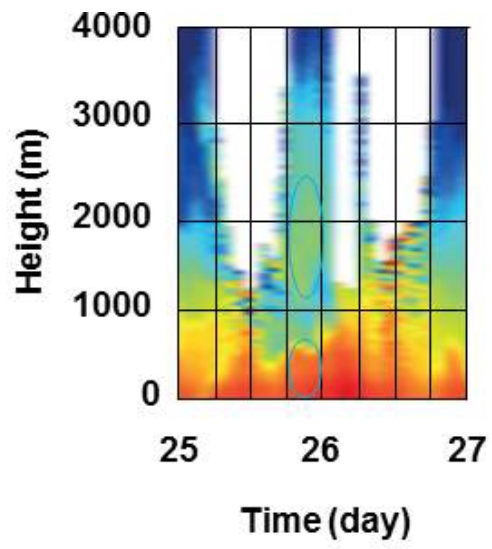

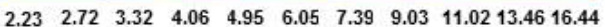
WALI - WVMR (g kg-1)

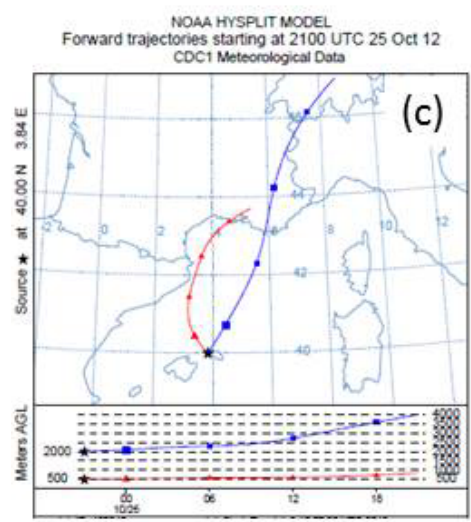

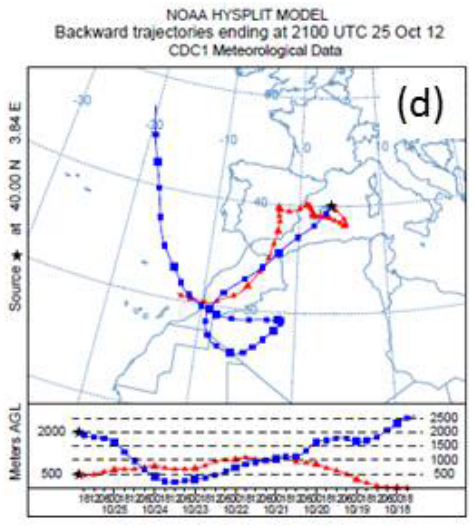

Figure 3. (a) Spatial distribution of $24 \mathrm{~h}$ averaged GPS-derived IWV (mm) on 25 (a, b) and 26 (c-e) October 2012. (b) Time evolution of the water vapor mixing ratio $\left(\mathrm{g} \mathrm{kg}^{-1}\right)$ as measured by the ground-based lidar WALI in Menorca over the 48 $\mathrm{h}$ period from 00:00 UTC on 25 October 2012 to 00:00 UTC on 27 October 2012. (c) $24 \mathrm{~h}$ forward-trajectory analysis from HYSPLIT starting in Ciutadella (Menorca) at 21:00 UTC on 25 October 2012 and ending at 21:00 UTC on 26 October 2012. (d) $200 \mathrm{~h}$ back-trajectory analysis from HYSPLIT ending in Ciutadella (Menorca) at 21:00 UTC on 25 October 2012. (e) Vertical profiles of the water vapor mixing ratio $\left(\mathrm{g} \mathrm{kg}^{-1}\right)$ as measured by the ground-based lidar BASIL in Candillargues at different times on 26 October 2012.

trajectory model; Draxler and Hess, 1998; Rolph et al., 2017; Stein et al., 2015) and the information derived from the GPS network.

In Fig. 3a, the spatial distribution of the $24 \mathrm{~h}$ averaged GPS-derived IWV on 25 and 26 October 2012 shows initially higher atmospheric moisture content in the western area, where convection initiation takes place, whereas on the next period the humid air mass has advanced eastwards. The water vapor mixing ratio as measured by WALI in Ciutadella (Menorca) (Fig. 3b) reveals the presence of two distinct humid layers in the time interval 18:00-00:00 UTC on 25 October 2012: a surface layer extending up to about $0.6 \mathrm{~km}$, with mixing ratio values up to $\sim 12 \mathrm{~g} \mathrm{~kg}^{-1}$, and an elevated layer extending from 1.1 to $2.5 \mathrm{~km}$, with mixing ratio values up to $6-7 \mathrm{~g} \mathrm{~kg}^{-1}$. The $24 \mathrm{~h}$ forward-trajectory analysis starting in Ciutadella at 21:00 UTC on 25 October 2012 at the altitudes of the observed humidity layers (Fig. 3c) shows the north- ward movement of the surface humid layer, while air masses within the elevated humidity layer moved northeastward. The latter are plausibly related to the inflow branch of WCBs, i.e., the blue part of the air mass trajectories in Fig. 2. The surface humid layer passed over Candillargues about 15-21 h later, as shown by the mixing ratio profile measurements carried out by BASIL and illustrated in Fig. 3e, possibly feeding the MCS forming close to the cyclone center over the CévennesVivarais region on the morning of 25 October. Indeed, the water vapor profile shown in Fig. 3e is consistent with the one provided by LEANDRE 2 on board the ATR42 aircraft that flew over the WMed (Fig. 12 in Flaounas et al., 2016). The $24 \mathrm{~h}$ forward-trajectory analysis also reveals that air masses within the elevated humid layer passed over the Gulf of Lion, possibly ending up feeding the offshore MCS. Figure $3 \mathrm{~d}$ additionally illustrates the $200 \mathrm{~h}$ back-trajectory analysis ending in Minorca at 21:00 UTC on 25 September 2012 at the al- 
titudes (500 and $2000 \mathrm{~m}$ ) at which the two humid layers were observed, revealing that air masses within the surface humidity layer originated over the tropical Atlantic Ocean approximately $8 \mathrm{~d}$ earlier and passed over Morocco and southern Spain, slowly subsiding (in the last $72-96 \mathrm{~h}$ before the formation of the MCS) upon reaching the Mediterranean basin from an altitude of $1000 \mathrm{~m}$ down to $500 \mathrm{~m}$, whereas the air masses within the elevated humid layer originated over central Africa (northern Mali) approximately $3 \mathrm{~d}$ earlier and transited over Mauritania and Morocco before reaching the Balearic Islands.

\subsection{Low-level dynamical processes}

Once the synoptic setting becomes favorable for heavy precipitation in the WMed, with an upper-level trough slowly evolving eastward while deepening over the basin, the mesoscale organization and the thermodynamic characteristics of the low-level flow determine the occurrence, intensity, and location of heavy precipitation. Most of the severe rainfall events that occurred during the SOP1 field campaign can be connected to or at least interpreted in the framework of recent theoretical results concerning moist orographic convection (Miglietta and Rotunno, 2014; Kirshbaum et al., 2018). However, their in-depth analysis has revealed a greater complexity of real meteorological situations due to nonstationarity, the complexity of the real 3D orography and vertical profiles, and especially the interaction among small-scale processes, which are not entirely accounted for in controlledenvironment numerical experiments. One of the merits of HyMeX has been to provide evidence of the theoretical results and to enrich our knowledge of the genesis and evolution of convection in a complex topography environment through a plethora of modeling simulations and tools, as well as advanced instrument observations.

With heavy orographic precipitation in stable and neutral atmospheric conditions having already been investigated in past experiments (e.g., MAP - the Mesoscale Alpine Programme; Bougeault et al., 2001) and being well understood, the focus of HyMeX was on the development of quasistationary MCSs, which are well known to be responsible for recent HPEs and floods in the area (Nuissier et al., 2008; Buzzi et al., 2014; Romero et al., 2014 among others). These systems are characterized by "back-building" processes that force the continuous redevelopment of deep convective cells over the same area, producing severe and persistent rainfall (Schumacher and Johnson, 2005; Ducrocq et al., 2008; Duffourg et al., 2018; Lee et al., 2018). The multicell MCSs resulting from this retrograde regeneration assume a typical $\mathrm{V}$-shaped pattern in radar and satellite images. In this context, conditionally unstable marine flow directed towards the coastal mountainous regions and extracting energy from the sea surface has been pointed out as a common feature of all the events. However, different convection-triggering mechanisms have been identified and highlighted.

\subsubsection{Convection-triggering mechanisms}

Low-level convergence over the sea can initiate convection even far from the coast, and usually it is produced by largescale forcing. During IOP16 (Duffourg et al., 2016) the cyclonic circulation around a shallow low-pressure system was responsible for low-level convergence against the southeasterly flow between the Balearic Islands and the Gulf of Lion (Fig. 4a). Lee et al. (2016) revealed the key role during IOP13 of an approaching cold front in modifying the lowlevel circulation over the Tyrrhenian Sea, establishing favorable dynamical conditions for convection initiation. Even for IOP8, the low-level convergence that first triggered convection south of the Iberian Peninsula was ascribed to the large-scale setting (Röhner et al., 2016; Khodayar et al., 2015), even if orographic effects were essential to enhance mesoscale uplift over land during the mature phase of the convective system.

In fact, due to the peculiar topographic characteristics of the basin, in most of the events it is the interaction with the orography that triggers and eventually maintains convection, since it not only provokes the direct lifting, but can also produce the convergence required to initiate vertical motions. Several numerical experiments (Barthlott and Davolio, 2016) clearly showed the effects of Corsica and Sardinia on the downstream low-level wind as well as on temperature and moisture distribution. In particular, the deflection of the westerly-southwesterly flow due to the complex orography of the islands was identified as a key mechanism for the organization of heavy precipitation along the western Italian coast, since it determined small-scale complex patterns of low-level convergence over the sea in the lee of Corsica, where convection was triggered (Fig. 4b). Moreover, the interaction between sea breezes and drainage winds induced by mountainous islands like Corsica and Sardinia (Barthlott and Kirshbaum, 2013; Barthlott et al., 2016) impacts the development of deep convection both offshore and anchored to topographic features. Also, the flow splitting around Corsica can be a key mechanism producing a lee-side convergence line where a severe and stationary convective system develops (Scheffknecht et al., 2016).

Interestingly, the study of Lee et al. (2017) clearly indicated that neither an offshore convergence line nor the orographic uplift alone would have been enough to allow the development of the intense MCS that affected the Ebro River valley during IOP15 (Fig. 4c). It was their interplay that produced deep convection, together with the simultaneous presence of flow channeled by the local orography converging with the low-level marine inflow. This represents a clear example of the complex interaction among processes that HyMeX was able to highlight.

Low-level convergence induced by the blocking effect of mountain chains on the impinging flow is another frequent lifting mechanism upstream of the orography. Well before the HyMeX SOP, it was demonstrated that flow blocking 

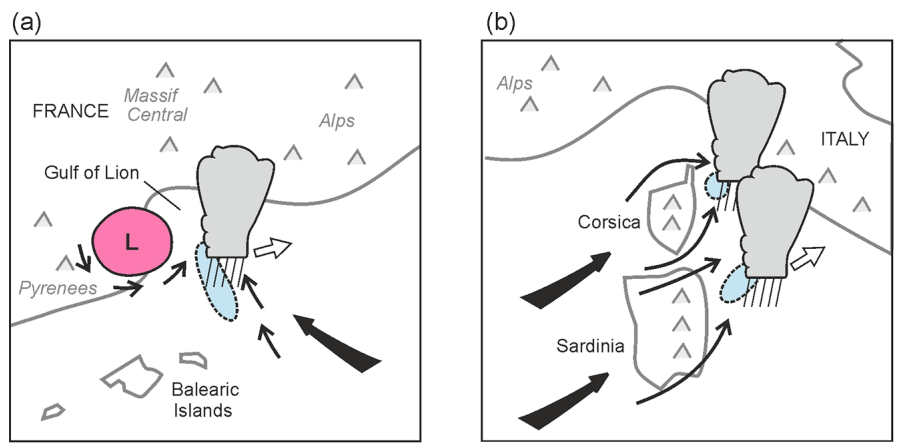

(d)

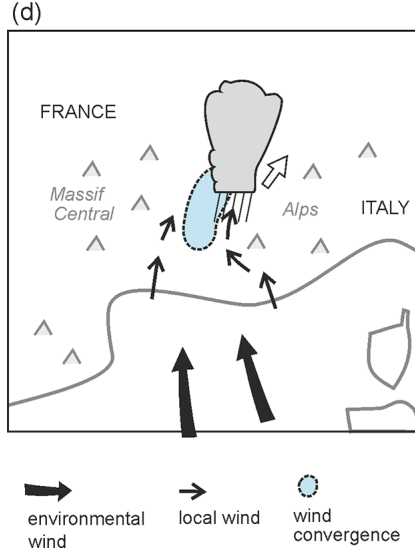

(e)

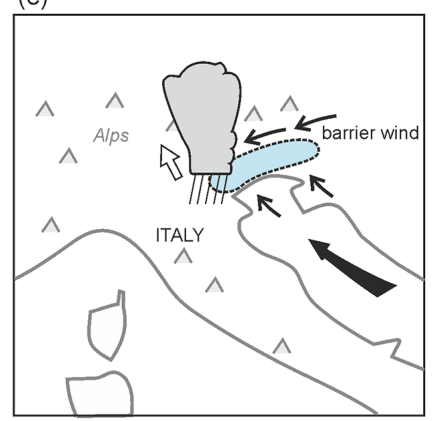

$\sum_{\begin{array}{l}\text { minnective } \\ \text { system }\end{array}} \Rightarrow$

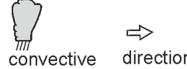

(c)

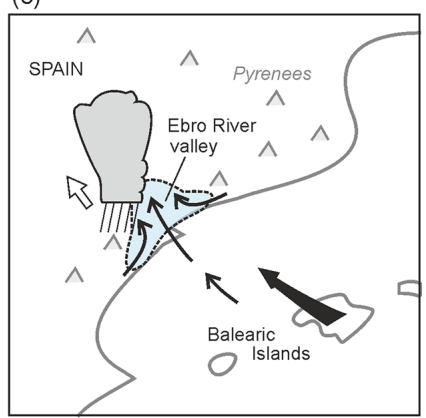

(f)

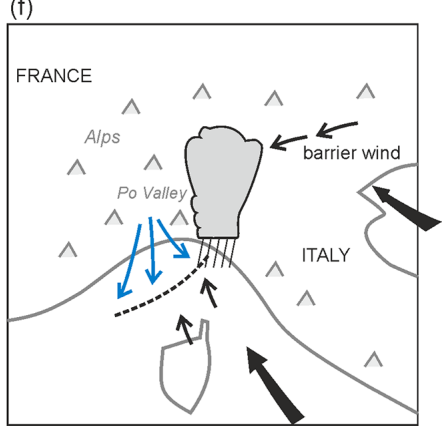

$\begin{array}{lll}\wedge & -\ldots . .0 & \rightarrow\end{array}$

Figure 4. Conceptual illustrations of key convection-triggering mechanisms in the northwestern Mediterranean basin. Coastlines are depicted by grey solid lines.

in front of Massif Central and the enhanced convergence due to deviation of southerly flow around the Alps (Fig. 4d) (Ducrocq et al., 2008; Davolio et al., 2009) were responsible for several HPEs over southeastern France, affecting areas well upstream of the main orographic reliefs. SOP-related studies identified a similar low-level flow characteristic associated with heavy rainfall over northeastern Italy. In both the analyzed events that occurred during IOP2b (Manzato et al., 2015; Miglietta et al., 2016) and IOP18 (Davolio et al., 2016), the blocking of southerly low-level marine inflow in the form of a northeasterly barrier wind in front of the Alps produced strong and localized convergence, favoring convection triggering (Fig. 4e). Through additional modeling investigations of similar events in the past, this was recognized as a typical mechanism for deep convection (even supercell) development over the area.

The importance of orographic interaction has also been revealed for the development of lee-side convection. Pichelli et al. (2017), through several numerical simulations of IOP6, illustrated the complex and delicate equilibrium between competing processes (orographically induced subsidence on the lee side and frontal uplift) that determined the evolution of a squall line over the Po Valley, on the lee side of a mountain range (Apennines), with respect to the main southerly flow feeding the precipitation.

\subsubsection{Cold pools}

The detailed observational and modeling analysis of IOP13 revealed that, as expected, direct orographic uplift can also trigger convection close to the coastal slopes. However, thanks to detailed observations and modeling simulations of the precipitation system and of the upstream environment, Duffourg et al. (2018) were able to provide a thorough description of the mechanisms that maintained the MCS while slowly moving offshore. In fact, the formation of an evaporative cold pool under the precipitating cells generated downvalley flows that slowly shifted the location of the backbuilding convective cells from the mountain to the coast and over the sea.

In this regard, it was emphasized (Lee et al., 2018) that the moisture vertical distribution in the lower troposphere can modulate the intensity of the cold pool and thus control the location and amount of heavy precipitation associated with the MCS. In several other events, the leading edge of a cold pool, formed by evaporative cooling under the precipitating cells, was able to trigger convection by lifting the impinging ambient low-level flow. Ramis et al. (1994) already pointed out the convergence associated with a cold pool boundary as a continued convection-triggering mechanism in the WMed. As suggested by idealized experiments with conditionally 
unstable flow over a mountain ridge (Bresson et al., 2012; Miglietta and Rotunno, 2009), the stationarity of the MCS or its upstream propagation away from the orographic barrier is determined by the intensity of the ambient flow. In this context, the vertical structure of the lower troposphere, in terms of moisture content and wind intensity, represents an important factor since it modulates the evaporation potential and thus the formation and intensity of the cold pool.

However, the presence of cold and dense air acting as a virtual mountain with respect to the impinging warm and moist flow can be due to different processes besides evaporative cooling. In the analysis of IOP8, Bouin et al. (2017) identified cold and moist air masses transported from the Gulf of Lion by the low-level jet. Despite their moisture content, these air masses were cold and dense enough so that their accumulation on the foothills of the relief contributed to initiating a cold pool. Once the MCS was triggered, rain evaporation in the subsaturated mid-level layer resulted in downdrafts that further intensified the cold pool, favoring the regeneration of the precipitation system. Finally, investigation of heavy precipitation over Liguria in IOP16 as well as in previous dramatic HPEs, undertaken within the HyMeX framework, provided a clear picture of the mechanisms responsible for recent and recurrent disastrous floods along the Ligurian Sea coast. Several studies (Buzzi et al., 2014; Fiori et al., 2017, among others) pinpointed the role of the cold air outflow from the Po Valley across the Apennine gaps, which propagated as a density current to the Ligurian Sea, where it determined a sharp mesoscale convergence line (sketched in Fig. 4f). Along such a convergence line, the lifting of southerly moisture-laden flow produced the onset of the severe convection. Interestingly, the cold flow over the sea appeared to be induced by an easterly inflow into the Po Valley from the Adriatic side, possibly due to a barrier wind effect over the northeastern Alps as previously described. As observed in many other cases (e.g., Duffourg et al., 2016), although the V-shaped structure seems anchored over the sea, a few tens of kilometers offshore, intense convective cells are continuously advected inland where HP occurs. Finally, Duffourg et al. (2016) also highlighted an interesting feedback process of convection to the environment that, through small-scale perturbations of the low-level circulation around the cold pool, focused and reinforced the local moisture convergence feeding the convective updraft.

\subsection{Impacts of the land and the sea surfaces}

\subsubsection{Land conditions and feedback to the atmosphere}

Land conditions and feedbacks between the land surface and the atmosphere play a role in determining the response of the Earth system to climate change, particularly in the Mediterranean region, which is a transitional zone between dry and wet climates. Indeed, enhanced land-atmosphere feedbacks are expected in a warming climate, and their understanding and simulation are challenging but fundamental to further improve our knowledge about future climate and their interactions with the other components of the climate system. Despite its relevance, the modeling of land-atmosphere feedback still suffers from relevant uncertainty owing to inaccurate initialization, model physics, and/or misspecified parameters. Helgert and Khodayar (2020) showed that the response of western Mediterranean HP to extreme soil moisture (SM) initial conditions impacts the mean, but also the extremes of precipitation, and that an improvement of soil-atmosphere interactions and subsequent HP modeling is observed using an enhanced initialization with remotely sensed $1 \mathrm{~km} \mathrm{SM}$ information. Regional projections of precipitation under the RCP4.5 and RCP8.5 scenarios have been shown to be considerably modified when SM is used as a predictor (Hertig et al., 2018). Therefore, better knowledge and representation of soil conditions and evolution must be considered for HP understanding and modeling.

\subsubsection{Air-sea interactions and coupling}

The Mediterranean Sea and the atmospheric boundary layer (ABL) continuously exchange momentum, heat, and fresh water. These exchanges, related to turbulent fluxes, are controlled by the gradients of temperature, humidity, and velocity at the air-sea interface. Rainaud et al. (2015) showed that although moderate air-sea fluxes were observed during the HPEs of SOP1, large air-sea exchanges in the Gulf of Lion and the Balearic, Ligurian, and Tyrrhenian seas can be correlated with the occurrence of an HPE. The SST strongly influences the low-level flow stability and dynamics through heating, moistening, and downward momentum mixing (Stocchi and Davolio, 2017; Meroni et al., 2018a). SST is indeed a key parameter for evaporation (Fig. 5a), and its influence on HPEs in terms of convection triggering, intensity, and location has been extensively investigated with several numerical studies (e.g., Strajnar et al., 2019; Senatore et al., 2020b, for some of the most recent). Generally, these studies highlight the fact that the SST values strongly and directly modify the low-level atmospheric stability, which first impact the intensity of convection and precipitation, with the most intense rainfall associated with a warmer sea surface. The location and stationarity of heavy precipitating systems are also modified, with an acceleration of the low-level wind velocity over a warmer sea, but also by the fine-scale SST horizontal patterns with eddies and marked fronts in the Mediterranean (as explicitly simulated in the coupled forecast of Rainaud et al., 2017, for IOP16a shown in Fig. 5a) that can significantly change the flow dynamics interacting with orography (Davolio et al., 2017) or displace the moisture convergence at sea (Rainaud et al., 2017; Meroni et al., 2018a).

During intense meteorological events in the Mediterranean such as HPEs, significant modifications of the ocean mixed layer (OML) can occur, even on short timescales of only several hours (Lebeaupin Brossier et al., 2014), and can sig- 

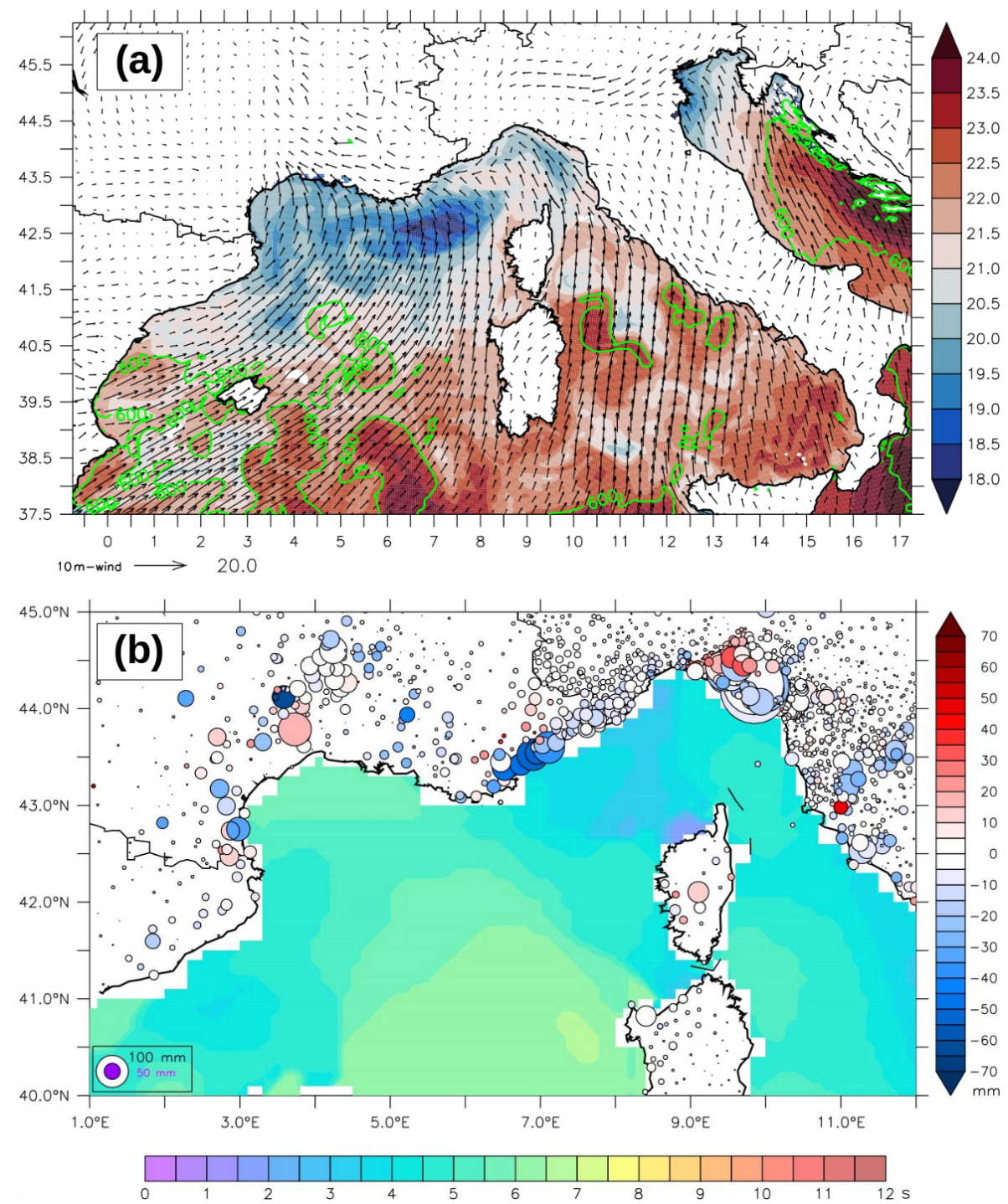

Figure 5. (a) Daily mean SST (colors, ${ }^{\circ} \mathrm{C}$ ), $10 \mathrm{~m}$ wind (arrows, $\mathrm{m} \mathrm{s}^{-1}$ ), and surface evaporation (green contours for values above $600 \mathrm{~kg} \mathrm{~m}^{-2}$ ) for 26 October 2012 (IOP16a) from the AROME-NEMO WMED coupled experiment (CPLOA) of Rainaud et al. (2017). (b) Peak period of waves (color, s) at 00:00 UTC on 26 October 2012 considered in Thévenot et al. (2016) and bias modification (circles, mm) for $24 \mathrm{~h}$ rainfall accumulation against rain gauge data, comparing Meso-NH simulations with (WAM) and without (NOWAV) sea state impact (blue for an improvement in WAM). The size of the circles indicates the NOWAV bias (absolute value, in mm).

nificantly impact the exchanges with the ABL. Berthou et al. (2016) showed that IOP16a was likely sensitive to SST changes upstream related to OML changes and sub-monthly air-sea coupling. The ocean vertical stratification is also a characteristic that has to be accounted for, as sea surface cooling during HPEs is largely controlled by the entrainment of deeper and colder water in the OML. The study of Meroni et al. (2018b), using coupled experiments with idealized ocean conditions, highlights the fact that the cooling is more pronounced with a shallow, strongly stratified OML, leading to lower air-sea fluxes, less air instability, and finally a reduction of the total amount of simulated precipitation.
The use of ocean-atmosphere coupled systems enables us to consider the ocean 3D structure and its interactive and consistent evolution. Such modeling systems were specifically developed in the framework of HyMeX to improve the realism of weather forecasts for sea surface and atmospheric low levels, and they have been innovatively evaluated thanks to the multi-compartment observational dataset. For IOP16a, Rainaud et al. (2017) showed that, due to mixing and heat loss, the progressively lower SST in the coupled model induces lower heat fluxes $(-10 \%$ to $-20 \%$ of evaporation), local differences in the low-level environment (stability), and cyclonic circulation, with small impacts on the convection organization (convergence) and intensity. 
Waves also impact the atmospheric low levels by increasing the surface roughness and the momentum flux, and they act as a drag for the low-level upstream flow. For HPEs, in forced and coupled simulations, this slowdown results in modification of the HP location due, for instance, to changes in the low-level flow, convergence line, or cold pool motion over the sea (Bouin et al., 2017; Sauvage et al., 2020). The study of Thévenot et al. (2015) highlighted this wave's impact in the IOP16a case, with a better representation of the low-level moist jet feeding the MCSs and of the simulated precipitation when the sea state is considered in the bulk formulae (Fig. 5b).

\subsection{Microphysics}

Many advances in the understanding and knowledge of cloud composition and microphysical processes in Mediterranean convective systems were attained in the framework of HyMeX, thanks to the large number of observations used in process, modeling, and/or data assimilation studies.

Among them, a large number of available disdrometers and MRRs were used to improve the quality of observations (Raupach and Berne, 2016; Adirosi et al., 2016) and the characterization of raindrop PSD (Adirosi et al., 2014, 2015; Schleiss and Smith, 2015), including its very smallscale variability (Gires et al., 2015).

Based on rain gauge observations over a long period encompassing the HyMeX experiment, Molinié et al. (2012) studied the rainfall regime in a mountainous Mediterranean region in southeastern France. They found that rainfall intermittency at both the monthly and daily scales is well correlated with the rain gauge altitude, which is also linked to rainfall intensity. Zwiebel et al. (2015) and Hachani et al. (2017) also found that several factors (altitude, season, weather type, among others) influence both the rainfall characteristics at the ground and the relationship between rainfall rate and the reflectivity factor.

Other studies focused on the use of radar data to investigate cloud composition. Grazioli et al. (2015) proposed a hydrometeor classification algorithm using an X-Band radar (deployed in Ardèche during HyMeX SOP1). Ribaud et al. (2015) also developed a hydrometeor classification algorithm using dual-polarimetric radars and produced 3D hydrometeor fields when several radars were available. Using this classification, they also identified a link between cloud characteristics and lightning propagation (Ribaud et al., 2016).

HyMeX microphysical observations have also led to improvements in model physics and parameterizations. Fresnay et al. (2012) first demonstrated the sensitivity of Mediterranean HPE simulations to the cloud parameterization. Using several observations from HyMeX SOP1, Taufour et al. (2018) showed that the two-moment scheme LIMA (Vié et al., 2016) provides a more realistic cloud representation than the one-moment scheme ICE3. This is shown in Fig. 6, which presents the distribution of the simulated and observed RASTA reflectivities, sorted by altitude. Data from IOP6 and IOP16 were combined and classified in bins of altitude and reflectivity, and the number of events in each category was normalized by the total number of data points to provide the colored frequency. The shape of the reflectivity distribution is better represented by LIMA than ICE3, especially in the melting region. Furthermore, Taufour et al. (2018) proposed a revision of the LIMA scheme based on the disdrometer rain PSD observations.

Aerosol-cloud interactions were also found to have a strong impact on convective systems and rainfall characteristics (Kagkara et al., 2020), and the best simulation results with the two-moment LIMA scheme are obtained when using a realistic aerosol population from the MACC analyses validated against ATR42 observations (Taufour et al., 2018).

Eventually, some studies prepared for the future assimilation of cloud data. Augros (2015) implemented the assimilation of dual-polarization radar data in the French operational AROME model. Borderies et al. (2019a, b) proposed a method to assimilate airborne RASTA reflectivities and Doppler winds, meanwhile releasing an improved version of the RASTA simulator for use in mesoscale models.

\section{Improving heavy precipitation modeling across scales}

\subsection{Increasing model resolution simulations}

Idealized simulations of deep moist convection at kilometric scales (grid spacing: $4 \mathrm{~km}, 2 \mathrm{~km}, 1 \mathrm{~km}$, and $500 \mathrm{~m}$ ) showed that accumulated rainfall and corresponding surface area, as well as the area covered by the updrafts, increase with increasing resolution. At $4 \mathrm{~km}$ horizontal resolution, deep convection is under-resolved, and differences are larger between $1 \mathrm{~km}$ and $500 \mathrm{~m}$ horizontal resolution simulations than between 2 and $1 \mathrm{~km}$, suggesting the beginning of convergence at $500 \mathrm{~m}$ (Verrelle et al., 2014). Bassi (2014) analyzed several IOPs over the LT target area by performing numerical simulations at different grid spacings between 3 and $1 \mathrm{~km}$ and with different resolutions of the orography representation, showing that both aspects equally contributed to improving the quantitative precipitation forecast (QPF). In fact, the higher model resolution allowed a better description of the structure, vertical motions, and dynamical mechanisms of the convective system, whereas accurate orography was required to correctly simulate the propagation of the density current along the Apennine slopes and thus the precise location of the convergence line that triggered the MCS. In terms of microphysics parameters, discrepancies between models and observations could be attributed to the implementation of a one-moment microphysics scheme and to the coarse resolutions; hence, there is a need for grid spacing finer than $2.5 \mathrm{~km}$ (Augros et al., 2015). 

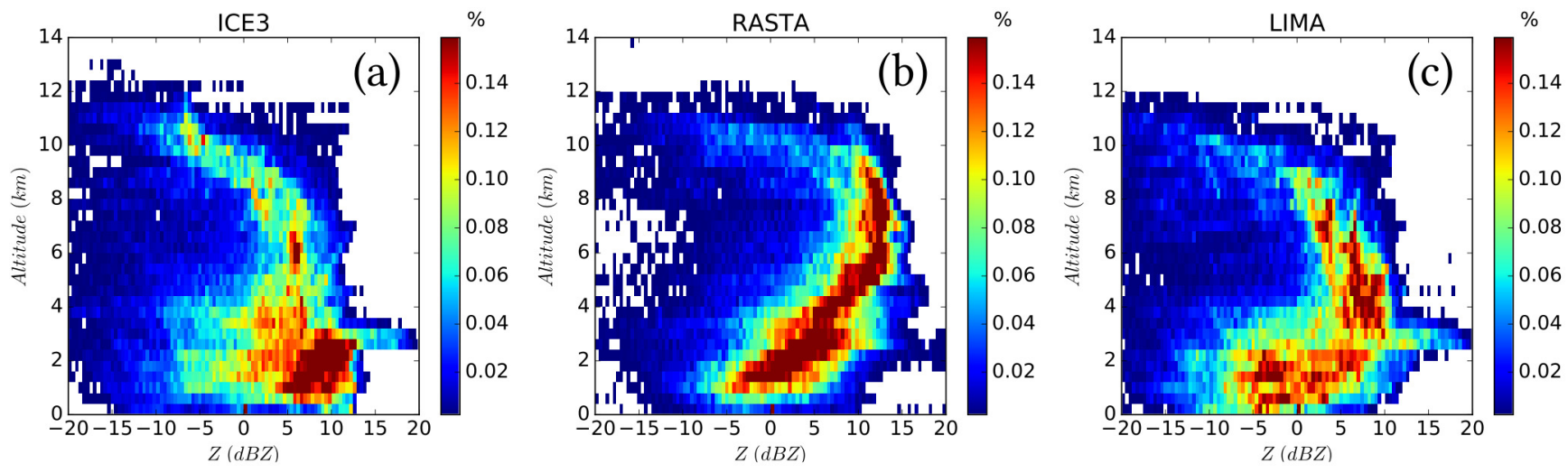

Figure 6. Distribution of simulated (a: ICE3, c: LIMA) and observed (b) RASTA reflectivities sorted by temperature, merging data from IOP6 and IOP16a (from Taufour et al., 2018 ).

The increase in horizontal resolution is therefore a great improvement, but it additionally poses challenges for the model physics since some parameterization schemes may become inappropriate. This is the case, for example, of the turbulence parameterization in the "grey zone" between $1 \mathrm{~km}$ and $100 \mathrm{~m}$ horizontal grid spacing (Wyngaard and Coté, 1971) and of one-moment microphysical schemes for which the overestimation of reflectivities at high altitude due to graupel is a known limitation (Varble et al., 2011).

Hectometric-scale simulations of a Mediterranean HP event at $150 \mathrm{~m}$ by Nuissier et al. (2020) were able to capture features regarding convective organization within the converging low-level flow, which are out of range of models with kilometric horizontal resolutions. However, the comparison of the large-eddy simulation (LES) with a reference simulation performed with a $450 \mathrm{~m}$ grid spacing in the heart of the so-called "grey zone" of turbulence modeling shows that the increase in resolution does not significantly reduce deficiencies of the simulation, with this fact being more related to an issue of initial and lateral boundary conditions.

\subsection{New generation of high-resolution convection-permitting simulations and improvement of RCMs}

One of the most remarkable advances in the last years with significant implications for HP simulation has been the development of the new generation of high-resolution convection-permitting models (CPMs). This development has been extensively fostered and exploited in HyMeXrelated activities and studies, and it represents one of the main innovations contributing to advancing knowledge of HP occurrence. Kilometric grid spacing has become achievable with the increasing availability of computational resources. As the horizontal resolution approaches $1 \mathrm{~km}$, parameterization of deep convection is no longer needed since much of the convective motion is explicitly resolved. It has been demonstrated that the reduction of the grid spacing leads to a weaker overestimation in the height and size of the convective cells (Caine et al., 2013), together with a more accurate representation of the timing and location of convection (Clark et al., 2016).

The benefit of higher-horizontal-resolution CPMs can also propagate along the forecasting chain to hydrological predictions. Simulating the catastrophic Liguria floods of 2011, Davolio et al. (2015) demonstrated that the finer grid resolution resulted in better QPF because of a more accurate description of the MCS and of its interaction with the orography, and this improvement was also confirmed in terms of discharge forecasts.

In a seamless weather-climate multi-model intercomparison, Khodayar et al. (2016a) showed that despite differences in their representation of an HPE, CPMs represented short intense convective events more accurately, whereas convection-parameterized models produce many weak and long-lasting events and RCMs produce notably lower precipitation amounts and hourly intensities. Figure 7 shows an example of how finer-resolution simulations better represent convergence over the sea, where warm and moist air is transported by a low-level jet towards the French coast. The higher resolution enhances the humidity convergence areas over the sea, which appear to be located further upstream, as well as the associated triggering of convection. Furthermore, the added value of convection-permitting with respect to RCMs has also been demonstrated in the northwestern Mediterranean basin (e.g., Berthou et al., 2018; Coppola et al., 2018; Fumière et al., 2019). Berthou et al. (2018) showed that convection-permitting RCM simulations (about $2.5 \mathrm{~km}$ grid spacing) better represented HPEs in southern France in terms of daily precipitation than their convection-parameterized counterparts (about $12.5 \mathrm{~km}$ grid spacing). The added value for the simulation of hourly rainfall over the United Kingdom, Switzerland, and Germany was also shown. Coppola et al. (2018), in a multi-model study, proved the ability of high-resolution CPRCMs to reproduce three events of HP, one in summer over Austria, one in fall associated with a ma- 
(a)

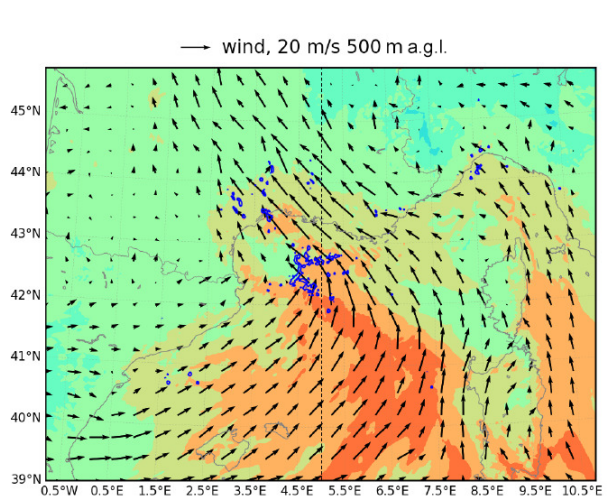

(c)

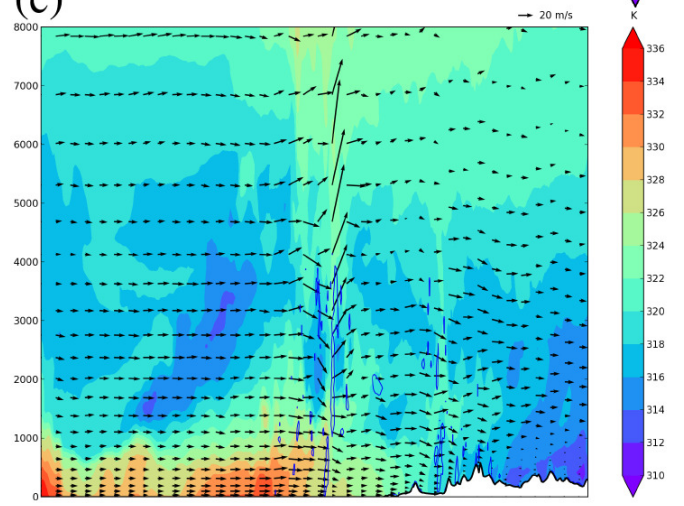

(b)

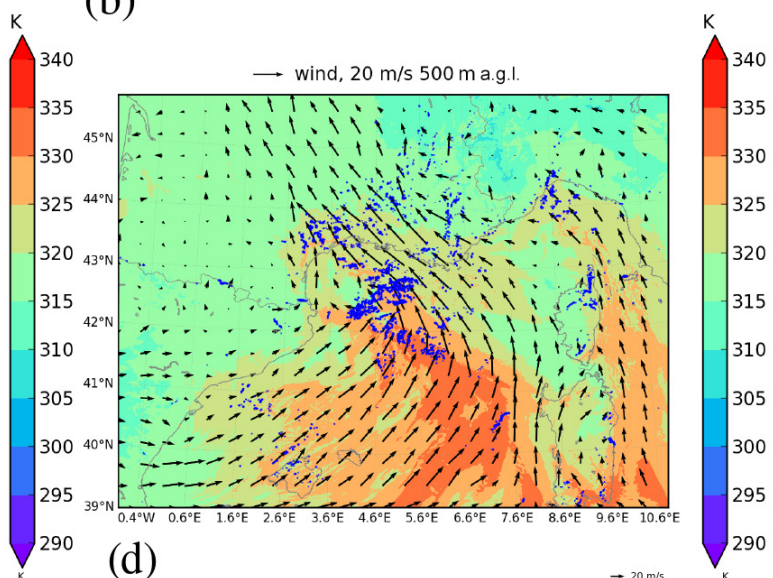

(d)

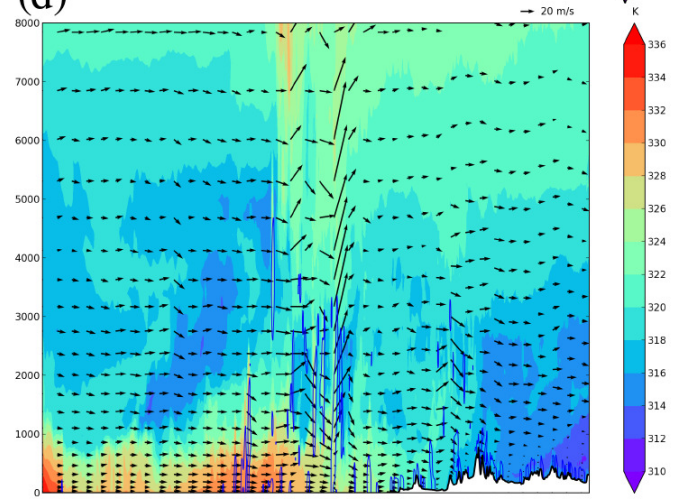

Figure 7. IOP16: 09:30 UTC, 26 October 2012. Horizontal cross sections at $500 \mathrm{~m}$ a.g.l. and vertical cross sections along a south-north line (shown in a) of equivalent potential temperature ( $\mathrm{K}$, in color scale), as well as wind vectors ( $\mathrm{m} \mathrm{s}^{-1}$, black arrows) for $2 \mathrm{~km}(\mathbf{a}, \mathbf{c})$ and $500 \mathrm{~m}$ $(\mathbf{b}, \mathbf{d})$ resolution runs. The blue lines represent the humidity convergence $\left(-0.1 \mathrm{~kg} \mathrm{~s}^{-1} \mathrm{~m}^{-3}\right.$ for vertical cross sections and $-0.02 \mathrm{~kg} \mathrm{~s}^{-1} \mathrm{~m}^{-2}$ integrated over the layer between the ground and $3000 \mathrm{~m}$ for horizontal cross sections).

jor foehn event over the Swiss Alps, and another intense fall event along the Mediterranean coast. In a dedicated study of Mediterranean HPEs in fall on an hourly timescale, Fumiere et al. (2019) demonstrated that high resolution allows for (a) the improved representation of the spatial pattern of fall precipitation climatology, (b) the improvement of the localization and intensity of extreme rainfall on daily and hourly timescales, and (c) the ability to simulate intense rainfall on lowlands.

\subsection{Improvement of parameterization schemes}

Recent studies have shown that the simulation of convective systems is very sensitive to model parameterizations. For IOP16a, Thévenot et al. (2015) showed that taking the sea state into account in turbulent air-sea exchanges can modify the low-level dynamics of the atmosphere and the precipitation location. However, the relationship of Oost et al. (2002) used in this study to compute the roughness length is known to overestimate the turbulent fluxes in strong wind regimes. A new formulation of sea surface turbulent flux parameterization is under development and currently being tested to better represent the wind-sea (i.e., the younger waves locally generated by wind) impact and related variability. The preliminary results when applied to HPE forecasts confirm the significant slowdown of the upstream low-level flow with displacement of convergence over the sea and show minor changes in the heat and moisture fluxes (Sauvage et al., 2020). Further developments are planned concerning sea surface flux computation, notably including the impact of sea spray on moisture and of the swell (i.e., the oldest nonlocal waves).

In Rainaud et al. (2015), a change in the SST or the coupling of atmospheric and oceanic models is found to have a large impact on the simulated precipitation amount over land. Martinet et al. (2017) investigated the sensitivity of simulated $\mathrm{HP}$ at a sub-kilometric scale $(500 \mathrm{~m})$ to the turbulence parameterization (i.e., Deardorff or Bougeault-Lacarrère), showing that the simulated environment and convective processes are highly sensitive to the formulation of the mixing length. Convective systems are more intense in association with larger moisture advection, higher hydrometeor contents, and marked low-level cold pools with weaker mixing lengths, since in this case the subgrid total kinetic energy (TKE) is weaker, and winds are increased to balance this effect. 
(a)

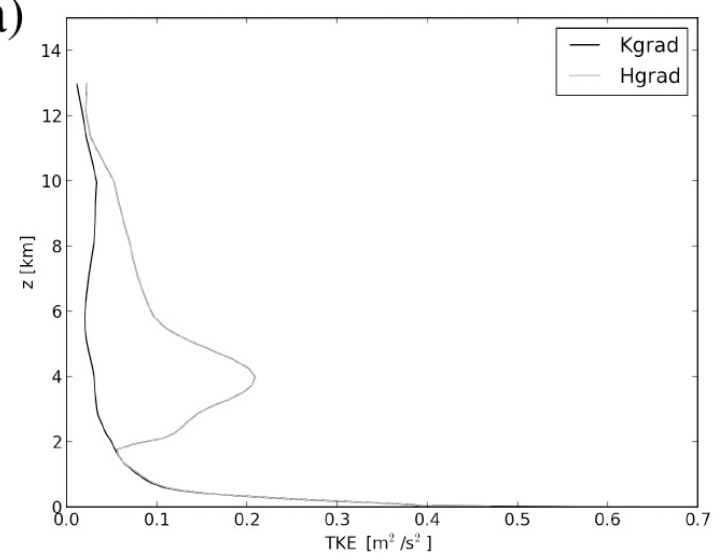

(b)

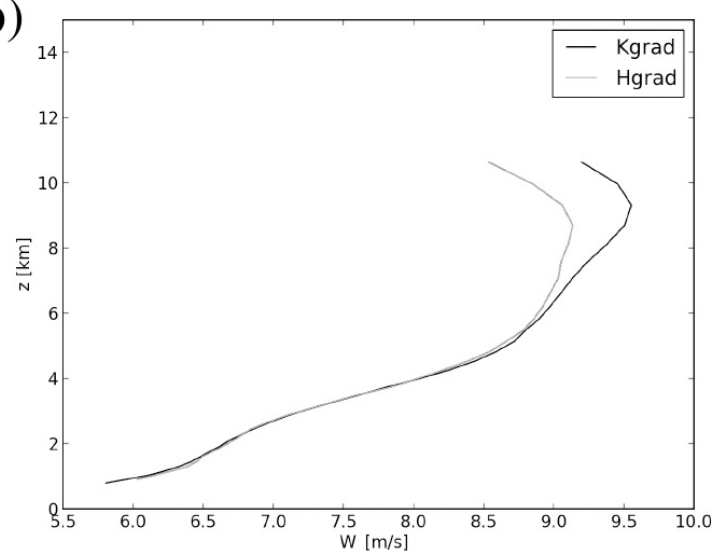

Figure 8. Mean vertical profiles inside the clouds of (a) subgrid TKE $\left(\mathrm{m}^{2} \mathrm{~s}^{-2}\right)$ and (b) vertical velocity ( $\left.\mathrm{m} \mathrm{s}^{-1}\right)$ during IOP16 (between 00:00 UTC on 26 October and 00:00 UTC on 27 October 2012) for $2 \mathrm{~km}$ horizontal resolution Meso-NH simulations using K-gradient formulation (black line) and $\mathrm{H}$-gradient formulation (grey line) for the vertical turbulent fluxes of heat and moisture.

Moreover, Verrelle et al. (2014) found insufficient turbulent mixing inside convective clouds that is more pronounced at kilometer resolution with weak thermal production, underlying a lack of entrainment in convective clouds at intermediate range (between $500 \mathrm{~m}$ and $2 \mathrm{~km}$ horizontal resolution). By using LES of deep convection, Verrelle et al. (2017) and Strauss et al. (2019) showed that the commonly used eddy diffusivity turbulence scheme (K-gradient formulation) underestimated the thermal production of subgrid TKE and did not enable the nonlocal turbulence due to counter-gradient structures to be reproduced. These two studies also found that the approach proposed by Moeng (2010), parameterizing the subgrid vertical thermodynamical fluxes in terms of horizontal gradients of resolved variables (H-gradient approach), reproduced these characteristics and limited the overestimation of vertical velocity. This new approach has also been assessed using Meso-NH simulations at kilometer-scale resolutions for real cases of deep convection on two HyMeX IOPs (IOP6 and IOP16a) (Ricard et al., 2021). The new scheme enhances the subgrid thermal production of turbulence with a better representation of counter-gradient areas and reduces the vertical velocity inside the clouds (Fig. 8). The enhanced turbulent mixing modifies the entrainment and detrainment rates and produces more developed anvils with increased values of ice and snow, which are more realistic. It also affects the cold pool under the convective cells.

\subsection{Data assimilation}

One of the HyMeX goals was to improve or develop research as well as operationally oriented atmospheric data assimilation systems and methods. Emphasis has been put on progress in the processing of observations currently available in data assimilation systems and on the assimilation of new observation types, especially aimed at improving the prediction of HP.
Campins and Navascués (2016) evaluated the impact of targeted observations on HIRLAM forecasts during HyMeX SOP1, showing that the assimilation of radiosoundings and Advanced TIROS Operational Vertical Sounder (ATOVS) satellite observations clearly improve the first-guess quality over land- and sea-sensitive areas, respectively. A realtime implementation of the HyMeX-dedicated version of the Météo-France AROME NWP system covering the whole WMed ran from 1 September 2012 to 15 March 2013 (Fourrié et al., 2015). The same system was used to perform an extensive reanalysis of SOP1 by exploiting observations from research instruments deployed during the campaign in addition to the operational observations assimilated in real time (Fourrié et al., 2019). For that, processing of observations and systematic comparisons between observations and AROME short-range forecasts were carried out for the following: (i) ground-based lidar water vapor observations in Candillargues (BASIL) and at Menorca (WALI); (ii) airborne lidar LEANDRE 2 water vapor observations along the SAFIRE/ATR42 flight tracks; (iii) high-resolution radiosoundings from operational sites in France and Spain and HyMeX-dedicated radiosoundings launched during SOP1 over France and Italy; (iv) dropsonde observations and in situ observations from the three research aircraft; (v) reprocessed wind profiler observations; (vi) reprocessed delays from more than 1000 GPS receivers over France, Spain, Portugal, and Italy; (vi) radar data from five AEMET operational radars over Spain; and (vii) additional SST observations from ships and Argo floats. The skill scores showed a better performance for the forecasts starting from the reanalysis than those starting from the real-time AROME-WMED analysis. Additional benefits were identified such as the detection of a secondary cyclone producing severe weather in Menorca during IOP18 (Carrió et al. 2020). 

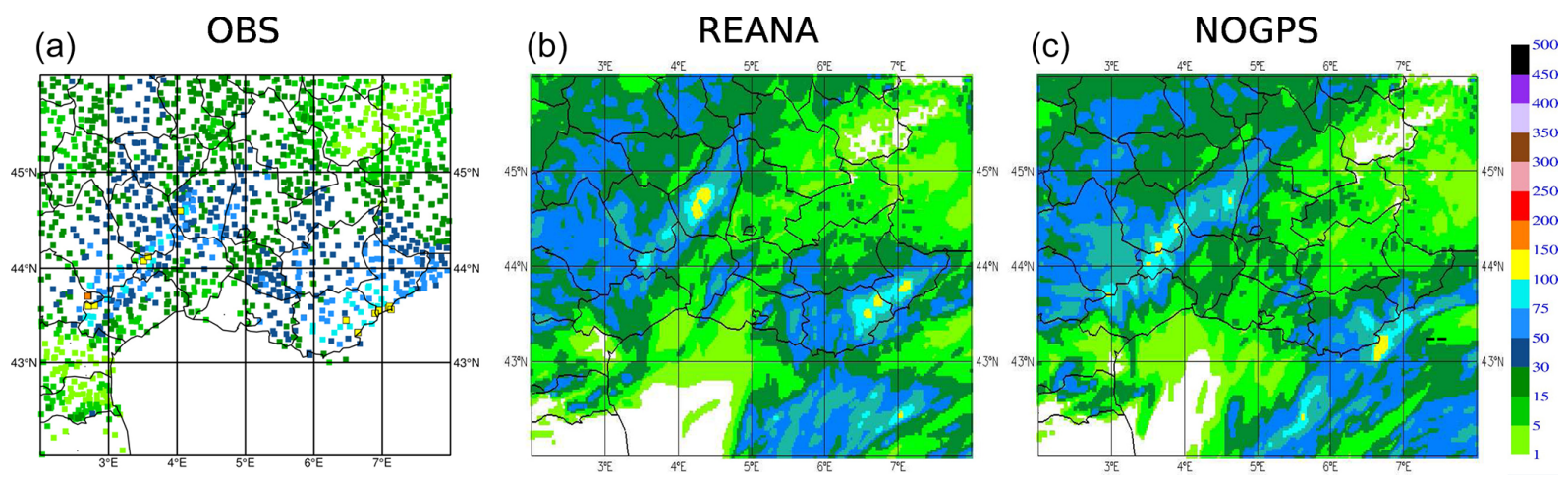

Figure 9. The $24 \mathrm{~h}$ accumulated precipitation (mm per $24 \mathrm{~h}$ ) between 06:00 UTC on 26 October and 06:00 UTC on 27 October 2012 over southern France (zoom over the Cévennes area); observations (a), REANA (b), and NOGPS (c) simulations.

Data denial experiments, for which one of the abovelisted datasets was removed from the reanalysis at a time, clearly showed the benefit of assimilating the reprocessed GPS ground-based zenithal total delays as shown in Fig. 9.

This result was confirmed in other studies. Lindskog et al. (2017) demonstrated the benefits of GPS assimilation for the forecast quality. Bastin et al. (2019) pointed out that the general overestimation of low values of IWV in RCM models over Europe was reduced when using a nudging technique to assimilate IWV information. Caldas-Alvarez and Khodayar (2020) and Caldas-Alvarez et al. (2021) highlighted the positive impact exerted by moisture corrections on precipitating convection and the chain of processes leading to it across scales. Furthermore, the implementation of nudging methodologies to exploit non-conventional observations, such as rainfall estimates from remote sensing, provided positive results in applications to both nowcasting and short-term meteo-hydrological forecasting (Davolio et al., 2017; Poletti et al., 2019).

The potential of several new types of observations within cloudy and precipitating systems has also been investigated. As a first step towards assimilation, "observation operators", which consist of simulating observations from model outputs, have been developed. In the framework of HyMeX, a dual-polarization weather radar simulator was developed in the post-processing part of the Meso-NH mesoscale model (Augros et al., 2015). An observation operator for the airborne RASTA reflectivity observations has also been developed (Borderies et al., 2019a). The impact of the assimilation of RASTA data on AROME-WMED analyses and forecasts has been assessed. IOP7a results indicated an improvement in the predicted wind at short-term ranges ( 2 and $3 \mathrm{~h}$ ) and in the $12 \mathrm{~h}$ precipitation forecasts. Over a longer cycled period, a slightly positive improvement in the 6,9 , and $12 \mathrm{~h}$ precipitation forecasts of heavy rainfall has been demonstrated (Borderies et al., 2019a). The assimilation of RASTA reflectivity data in AROME-WMED over the whole SOP1 period resulted in an improvement of rainfall forecasts even larger when wind was jointly assimilated (Borderies et al., 2019b).
Finally, HyMeX has fostered the inception of a collaboration between CNRM (France) and CNR-ISAC (Italy) concerning the assimilation of radar data. The assimilation of the radar reflectivity factor ,together with lightning, showed a significant and positive impact on the short-term precipitation forecasts (Federico et al., 2019).

\subsection{Predictability and ensemble forecasts}

Despite advances in numerical modeling and data assimilation, the prediction of HP and related floods remains challenging because predictability of intense convective systems is limited, and user expectations are very high given the impact of HPEs. Ensemble prediction techniques can provide solutions through the elaboration of probabilistic HPE warnings. Until the 2010s, regional ensemble prediction systems were mainly limited by the large computational costs of increasing the member resolution and the ensemble size. Ensemble forecasts become even more useful when post-processing techniques are applied to the precipitation fields using statistical methods such as regression or analogs (Diomede et al., 2014), with some difficulties due to the geographically complex forecast error structures of Mediterranean precipitation and the need to prepare very long reforecast datasets in order to adequately sample the statistical behavior of HPEs.

With the availability of more powerful computational resources, operational regional models started to reach the kilometric resolution, leading to physically more realistic convection-permitting ensemble prediction systems (CPEPSs). Studies of HPEs (Nuissier et al., 2016) have shown the added value of CPEPSs over deterministic approaches or lower-resolution ensembles. The enhanced exchange of validation datasets during HyMeX facilitated the objective verification of this kind of result in several ensemble studies such as Roux et al. (2019).

Several studies in the framework of HyMeX have demonstrated that, besides sensitivity to synoptic-scale forcing represented by lateral boundary condition (LBC) perturbations, 
CPEPSs were sensitive to multiple error sources, which had to be sampled as specific perturbation in the parameterization schemes. Some sensitivity of ensemble spread to the model physics (turbulence and microphysics schemes) was demonstrated in Hally et al. (2014), who used the HyMeX IOP6 and IOP7a forecast and observation dataset to show that LBC perturbations cannot be neglected and that the relative importance of LBC and physics uncertainties is casedependent, with physics uncertainty being more significant during weakly forced convective events. Vié et al. (2012) explored the impact of microphysical processes on CPEPS spread and found a relationship between precipitation evaporation and the uncertainty of cold pool formation, which can be relevant to predict the correct location of HPEs. Bouttier et al. (2015) found a beneficial impact of randomly perturbing surface fields such as SST or soil moisture: the high density of HyMeX SOP1 data gave statistical significance to these results because the objective verification of ensembles at high resolution requires large observational datasets.

Besides developing physics perturbation techniques, other ensemble approaches were tested in HyMeX case studies based on different models or parameterization schemes. This multiphysics or multi-model technique was shown to be relevant to HPEs in several studies, such as Davolio et al. (2013), Hally et al. (2015), and Ravazzani et al. (2016). Compared to other sources of uncertainty, the maximum impact of physics, multiphysics, or surface perturbations tends to be observed at forecast ranges between a few hours and about $1 \mathrm{~d}$, after which the CPEPS behavior is usually dominated by the LBCs.

The specification of the ensemble LBCs can be optimized in terms of the HPE forecasts: Nuissier et al. (2012) showed that LBC member selection from a global ensemble using a clustering technique improves compared to a random selection. Marsigli et al. (2014) demonstrated that direct nesting into the ECMWF ensemble, instead of using an intermediate model, is beneficial despite the large resolution jump between the global and CP ensemble.

Initial condition perturbations using ensemble data assimilation systems were studied in Vié et al. (2012) and Bouttier et al. (2016). They found that initial condition perturbations are critical to achieve a correct CPEPS ensemble spread, typically during the first $12 \mathrm{~h}$ of prediction, after which other perturbation sources (LBCs, surface and stochastic model perturbations) tend to dominate.

Verification of ensemble forecasts of HPEs can be overtaken using probabilistic scores. It greatly benefits from the large number of observations available during the SOPs. Ensemble predictions can also be evaluated by their ability to drive ensembles of hydrological runoff models. Indeed, it was confirmed during HyMeX that although hydrological models suffer from their own uncertainties (Edouard et al., 2018), precipitation forecast errors are the main sources of uncertainty for flood prediction. Many studies dealing with CPEPSs also exploited precipitation forecasts to drive

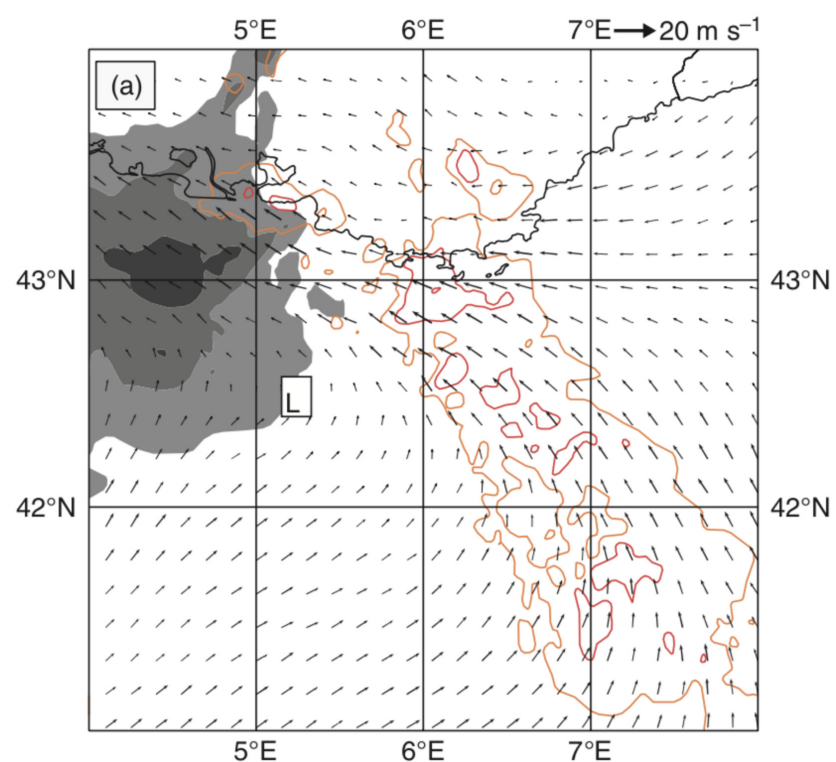

Figure 10. Lowest quartile of the mean sea level pressure (shading), mean $10 \mathrm{~m}$ wind (arrows), and mean moisture flux at $925 \mathrm{hPa}$ (solid lines: 80 and $100 \mathrm{~g} \mathrm{~m} \mathrm{~s}^{-2}$ ) valid at 12:00 UTC on 26 October 2012 for the AROME-EPS ensemble (credit: Nuissier et al., 2016).

flood prediction systems. Among others, Roux et al. (2019) pointed out that enhancing the spread of HPE forecasts tends to help flood warnings by improving the detection of extreme HPE scenarios.

An emerging application of CPEPS forecasts consists of investigating the physical mechanisms that drive HPEs (and, possibly, the reasons behind forecast failures), as exemplified in the USA by Nielsen and Schumacher (2016). In the HyMeX framework, besides the abovementioned studies on physical perturbations, the importance of orographically driven low-level flows was confirmed using CPEPSs in Hally et al. (2014) and Nuissier et al. (2016). Figure 10 shows an example for the IOP16 case.

\section{Discussion}

The spatial complexity of the Mediterranean region, the intricacy of the dynamical and physical processes involved including the multiple interactions across scales, and the technical and observational limitations in the past have made HP understanding and modeling in the Mediterranean region very challenging issues. To try to advance in this direction the Hydrological Cycle in the Mediterranean Experiment (HyMeX, 2010-2020) has put major effort into investigating the predictability and evolution of extreme weather events. Within this framework and profiting from state-ofthe-art observational datasets and modeling capabilities that have recently become available and been developed within the program, important achievements towards improved un- 
derstanding of the mechanisms leading to HP in the WMed have been accomplished. In this paper we review the main advances and lessons learned during HyMeX, including results that emerged from cross-disciplinary studies.

The unprecedented richness of observations and numerical experiments during HyMeX led to major achievements and the identification of primary needs for an improved understanding and predictability of HPEs. Among others, the following examples illustrate the main accomplishments achieved during HyMeX: our better comprehension of the moist convergence role in MCS initiation over the sea, the first-time airborne observations of WCB, measurements with high space-time resolution of the $3 \mathrm{D}$ fields of water vapor, and the testing of new convection-permitting ensembles, which provided new insights on HPE predictability and forecast error sources. Parallel to this, observational, modeling, and knowledge gaps have been identified, clearly indicating the need for future applications. Sensitivity to soils and sea surface conditions with impacts on high-resolution forecasts pointed out the need to build and/or improve highresolution coupled systems able to represent the full evolution of the soil and ocean conditions. A higher number of observations, for example collected over the sea, thermodynamic profile measurements and wind at a high space-time resolution would have a major impact on forecasting capabilities through the initialization of modeling systems, data assimilation, and the definition of improved parameterization schemes for turbulence and convection. Also, open questions remain regarding access to large samples of HPE reforecasts, the representation of model error processes specific to HPE systems, and persisting shortcomings in the real-time prediction of extreme precipitation events for flood warnings, among others. Furthermore, coordinated research efforts will be needed to address topics of multi-scale interactions, from large-scale dynamics to microphysical processes.

Along with the achievements and demands, the continuous collaboration between scientific communities, e.g., oceanographers and meteorologists, and among scientific teams (STs) has been a priority and a success of the project. In fact, coordinated efforts such as ST-lightning (lightning and atmospheric electricity), ST-TIP (towards integrated prediction of heavy precipitation, flash floods, and impacts), ST-ffv (flash floods and social vulnerabilities), and ST-medcyclones (Mediterranean cyclones), through the development and use of common observation and modeling tools and by sharing results and expertise, have helped towards achieving common goals. As an illustration, aiming at a better understanding of processes leading to flash floods and at their accurate modeling and forecasting, the ST-ffv actively contributed to the improvement of heavy rainfall prediction. Several recent multidisciplinary studies investigated the possibility to have an integrated modeling approach from heavy rainfall forecasting, to discharge prediction, to social impact. Methodologies of post-flood field surveys based on interdisciplinary collaborations between hydrologists and social scientists have been proposed (Ruin et al., 2014; Borga et al., 2019). For instance, Papagiannaki et al. (2017) investigated the link between HP and impacts on the flash flood that occurred in October 2015 in Attica. The survey responses provided insights into risk perception and behavioral reactions relative to the space-time distribution of rainfall. Different possibilities for improving hydrometeorological forecasts have also been tested (Roux et al., 2020), pointing out the added value of ensemble strategies with respect to deterministic forecasts. Large meteorological ensemble spreads also allowed better threshold exceedance detection for flood warning. Furthermore, the rapid increase in total lightning flash rates has been found to be an important predictor for severe weather phenomena (e.g., Wu et al., 2018), which is closely related to the rapid increase in graupel concentration and updraft volumes in the mixed-phase layers of deep convective systems. Furthermore, many studies in the framework of the ST-lightning have been devoted to the examination of the relationship of lightning activity with microphysical properties of convective systems along their life cycle. During HyMeX SOP1, the HyMeX lightning mapping array network (HyLMA; Defer et al., 2015) was operated to locate and characterize the 3D lightning activity over the Cévennes-Vivarais area at flash, storm, and regional scales. These unique and comprehensive lightning data clearly show the large potential for improving our knowledge about cloud microphysics, especially the distribution and evolution of ice hydrometeors by taking advantage of cloud electrification. This challenging subject is expected to be further addressed in the near future.

The increased computational capacity, the development of high-resolution convection-permitting models, and the availability of state-of-the-art observations have been demonstrated to be of pivotal importance to attain a better understanding and modeling of HP in the last decade. Nevertheless, the availability of observational data on the analysis of, e.g., small-scale processes still remains a limiting factor that challenges progress in process understanding and model evaluation, particularly when trying to underpin results from high-resolution model experiments with corresponding observations. Additionally, evaluation is expected to continue in those recent investigation lines developed within the HyMeX program, which have already demonstrated their usefulness for advancing prediction or knowledge of HPEs, such as CPEPSs or the development and availability of fully coupled soil-vegetation-atmosphere-ocean models. Furthermore, the benefit of working under the umbrella of a longlasting international experiment such as HyMeX allowed an effective and fruitful exchange of information on challenges, experiences, and goals, exploited through numerous multidisciplinary research activities. These interdisciplinary efforts were crucial to come towards improved understanding of the mechanisms leading to HP in the WMed. The links and networks originated in the framework of HyMeX must continue and even be enlarged in the future to progress together 
towards more integrated approaches. Novel integrated multidisciplinary research partnerships based on cross-sectional collaborations will indeed be needed for more efficient research on impacts.

Code and data availability. Given that this is a review publication, the data and code availability are provided in each of the referenced publications.

Author contributions. All authors collaborated and contributed to drafting, reviewing, and editing the paper. In particular, SK coordinated the effort and wrote the original draft; SD contributed to the reviewing of the low-level dynamical processes; PDG contributed to the reviewing of the observational capabilities; CLB contributed to the reviewing of the air-sea coupling; EF contributed to the reviewing of the large-scale dynamics; NF contributed to the reviewing of data assimilation; KOL contributed to the reviewing of the low-level dynamical processes; DR contributed to the reviewing of improved parameterizations; BV contributed to the reviewing of the microphysics; FB contributed to the reviewing of the predictability and ensemble forecast.

Competing interests. The authors declare that they have no conflict of interest.

Special issue statement. This article is part of the special issue "Hydrological cycle in the Mediterranean (ACP/AMT/GMD/HESS/NHESS/OS inter-journal SI)". It is not associated with a conference.

Disclaimer. Publisher's note: Copernicus Publications remains neutral with regard to jurisdictional claims in published maps and institutional affiliations.

Acknowledgements. This work is a contribution to the HyMeX program, supported in France by MISTRALS (Météo-France, CNRS, INRAE) and the Agence Nationale de la Recherche (ANR MUSIC grant ANR-14-CE01-0014, ANR IODA-MED grant ANR-11BS56-0005). We would like to thank all HyMeX contributors, particularly all members of the scientific team heavy precipitation (STHP, with more than 100 members in the last 10 years), who have effectively participated in advancing knowledge regarding heavy precipitation in the Mediterranean region. Without their work this study would not have been possible. We further acknowledge the HyMeX database developers and all data providers.

We also thank all HyMeX scientific team coordinators for the close cooperation during these years. We acknowledge Hélène Roux and Eric Defer for their input on research activities of the ST-ffv and ST-lightning. The authors thank Marie-Noëlle Bouin (CNRM \& LOPS), who provided us with Meso-NH simulation data related to IOP16a sensitivity to waves. The contribution of Paolo Di Girolamo to this work was possible based on support from the Ital- ian Ministry for Education, University, and Research under grants OT4CLIMA and FISR2019_01711 CONCERNING. The contribution of the first author Samira Khodayar Pardo was supported by the program Generacio Talent of Generalitat Valenciana (CIDEGENT/2018/017). Thank you to the two anonymous reviewers who helped us improve this paper with their comments.

Financial support. This work is a contribution to the HyMeX pro30 gram, supported in France by MISTRALS (Météo-France, CNRS, INRAE) and the Agence Nationale de la Recherche (ANR MUSIC grant ANR-14-CE01-0014, ANR IODA-MED grant ANR11-BS56-0005).

Review statement. This paper was edited by Farahnaz Khosrawi and reviewed by two anonymous referees.

\section{References}

Adirosi, E., Gorgucci, E., Baldini, L., and Tokay, A.: Evaluation of Gamma Raindrop Size Distribution Assumption through Comparison of Rain Rates of Measured and Radar-Equivalent Gamma DSD, J. Appl. Meteorol. Climatol., 53, 1618-1635, https://doi.org/10.1175/jamc-d-13-0150.1, 2014.

Adirosi, E., Baldini, L., Lombardo, F., Russo, F., Napolitano, F., Volpi, E., and Tokay, A.: Comparison of different fittings of drop spectra for rainfall retrievals, Adv. Water Resour., 83, 55-67, https://doi.org/10.1016/j.advwatres.2015.05.009, 2015.

Adirosi, E., Baldini, L., Roberto, N., Gatlin, P., and Tokay, A.: Improvement of vertical profiles of raindrop size distribution from micro rain radar using 2D video disdrometer measurements, Atmos. Res., 169, 404-415, https://doi.org/10.1016/j.atmosres.2015.07.002, 2016.

Adler, B., Kalthoff, N., Kohler, M., Handwerker, J., Wieser, A., Corsmeier, U., Kottmeier, C., Lambert, D., and Bock, O.: The variability of water vapour and pre-convective conditions over the mountainous island of Corsica, Q. J. Roy. Meteor. Soc., 142, 335-346, https://doi.org/10.1002/qj.2545, 2015.

Augros, C., Caumont, O., Ducrocq, V., Gaussiat, N., and Tabary, P.: Comparisons between S-, C- and X-band polarimetric radar observations and convective-scale simulations of the HyMeX first special observing period, Q. J. Roy. Meteor. Soc., 142, 347-362, https://doi.org/10.1002/qj.2572, 2015.

Barthlott, C. and Kirshbaum, D. J.: Sensitivity of deep convection to terrain forcing over Mediterranean islands, Q. J. Roy. Meteor. Soc., 139, 1762-1779, https://doi.org/10.1002/qj.2089, 2013.

Barthlott, C., Adler, B., Kalthoff, N., Handwerker, J., Kohler, M., and Wieser, A.: The role of Corsica in initiating nocturnal offshore convection, Q. J. Roy. Meteor. Soc., 142, 222-237, https://doi.org/10.1002/qj.2415, 2016.

Barthlott, C. and Davolio, S.: Mechanisms initiating heavy precipitation over Italy during HyMeX Special Observation Period 1: a numerical case study using two mesoscale models, Q. J. Roy. Meteor. Soc., 142, 238-258, https://doi.org/10.1002/qj.2630, 2016.

Bassi, C.: Modelli meteorologici ad alta risoluzione: simulazione di episodi di precipitazione intensa in Liguria e Toscana du- 
rante la campagna HyMeX, Università di Milano, available at: https://www.sba.unimi.it/en/thesis/49.html (last access: 28 Januray 2021), 2014.

Bastin, S., Drobinski, P., Chiriaco, M., Bock, O., Roehrig, R., Gallardo, C., Conte, D., Domínguez Alonso, M., Li, L., Lionello, P., and Parracho, A. C.: Impact of humidity biases on light precipitation occurrence: observations versus simulations, Atmos. Chem. Phys., 19, 1471-1490, https://doi.org/10.5194/acp19-1471-2019, 2019.

Berthou, S., Mailler, S., Drobinski, P., Arsouze, T., Bastin, S., Béranger, K., Flaounas, E., Brossier, C. L., Somot, S., and Stéfanon, M.: Influence of submonthly air-sea coupling on heavy precipitation events in the Western Mediterranean basin, Q. J. Roy. Meteor. Soc., 142, 453-471, https://doi.org/10.1002/qj.2717, 2016.

Berthou, S., Kendon, E. J., Chan, S. C., Ban, N., Leutwyler, D., Schär, C., and Fosser, G.: Pan-European climate at convectionpermitting scale: a model intercomparison study, Clim. Dynam., 55, 35-59, https://doi.org/10.1007/s00382-018-4114-6, 2018.

Bock, O., Bosser, P., Pacione, R., Nuret, M., Fourrié, N., and Parracho, A.: A high-quality reprocessed ground-based GPS dataset for atmospheric process studies, radiosonde and model evaluation, and reanalysis of HyMeX Special Observing Period, Q. J. Roy. Meteor. Soc., 142, 56-71, https://doi.org/10.1002/qj.2701, 2016.

Bonan, B., Albergel, C., Zheng, Y., Barbu, A. L., Fairbairn, D., Munier, S., and Calvet, J.-C.: An ensemble square root filter for the joint assimilation of surface soil moisture and leaf area index within the Land Data Assimilation System LDASMonde: application over the Euro-Mediterranean region, Hydrol. Earth Syst. Sci., 24, 325-347, https://doi.org/10.5194/hess-24325-2020, 2020.

Borderies, M., Caumont, O., Delanoë, J., Ducrocq, V., and Fourrié, N.: Assimilation of wind data from airborne Doppler cloudprofiling radar in a kilometre-scale NWP system, Nat. Hazards Earth Syst. Sci., 19, 821-835, https://doi.org/10.5194/nhess-19821-2019, 2019a.

Borderies, M., Caumont, O., Delanoë, J., Ducrocq, V., Fourrié, N., and Marquet, P.: Impact of airborne cloud radar reflectivity data assimilation on kilometre-scale numerical weather prediction analyses and forecasts of heavy precipitation events, Nat. Hazards Earth Syst. Sci., 19, 907-926, https://doi.org/10.5194/nhess19-907-2019, 2019b.

Borga, M., Comiti, F., Ruin, I., and Marra, F.: Forensic analysis of flash flood response, WIREs Water, 6, e1338, https://doi.org/10.1002/wat2.1338, 2019.

Bougeault, P., Binder, P., Buzzi, A., Dirks, R., Kuettner, J., Houze, R., Smith, R. B., Steinacker, R. and Volkert, H.: The MAP Special Observing Period, B. Am. Meteorol. Soc., 82, 433-462, https://doi.org/10.1175/15200477(2001)082<0433:tmsop>2.3.co;2, 2001.

Bouin, M.-N., Redelsperger, J.-L. and Brossier, C. L.: Processes leading to deep convection and sensitivity to seastate representation during $\mathrm{HyMeX}$ IOP8 heavy precipitation event, Q. J. Roy. Meteor. Soc., 143(707), 2600-2615, https://doi.org/10.1002/qj.3111, 2017.

Bouttier, F., Raynaud, L., Nuissier, O., and Ménétrier, B.: Sensitivity of the AROME ensemble to initial and surface perturba- tions during HyMeX, Q. J. Roy. Meteor. Soc., 142, 390-403, https://doi.org/10.1002/qj.2622, 2015.

Bresson, E., Ducrocq, V., Nuissier, O., Ricard, D., and de Saint-Aubin, C.: Idealized numerical simulations of quasistationary convective systems over the Northwestern Mediterranean complex terrain, Q. J. Roy. Meteor. Soc., 138, 1751-1763, https://doi.org/10.1002/qj.1911, 2012.

Brossier, C. L., Arsouze, T., Béranger, K., Bouin, M.-N., Bresson, E., Ducrocq, V., Giordani, H., Nuret, M., Rainaud, R., and Taupier-Letage, I.: Ocean Mixed Layer responses to intense meteorological events during HyMeX-SOP1 from a high-resolution ocean simulation, Ocean Model., 84, 84-103, https://doi.org/10.1016/j.ocemod.2014.09.009, 2014.

Buzzi, A., Davolio, S., Malguzzi, P., Drofa, O., and Mastrangelo, D.: Heavy rainfall episodes over Liguria in autumn 2011: numerical forecasting experiments, Nat. Hazards Earth Syst. Sci., 14, 1325-1340, https://doi.org/10.5194/nhess-14-1325-2014, 2014.

Caine, S., Lane, T. P., May, P. T., Jakob, C., Siems, S. T., Manton, M. J., and Pinto, J.: Statistical Assessment of Tropical ConvectionPermitting Model Simulations Using a Cell-Tracking Algorithm, Mon. Weather Rev., 141, 557-581, https://doi.org/10.1175/mwrd-11-00274.1, 2013.

Caldas-Álvarez, A., Khodayar, S., and Bock, O.: GPS - Zenith Total Delay assimilation in different resolution simulations of a heavy precipitation event over southern France, Adv. Sci. Res., 14, 157162, https://doi.org/10.5194/asr-14-157-2017, 2017.

Caldas-Alvarez, A. and Khodayar, S.: Assessing atmospheric moisture effects on heavy precipitation during HyMeX IOP16 using GPS nudging and dynamical downscaling, Nat. Hazards Earth Syst. Sci., 20, 2753-2776, https://doi.org/10.5194/nhess20-2753-2020, 2020.

Caldas-Alvarez, A., Khodayar, S., and Knippertz, P.: The impact of GPS and high-resolution radiosonde nudging on the simulation of heavy precipitation during HyMeX IOP6, Weather Clim. Dynam., 2, 561-580, https://doi.org/10.5194/wcd-2-561-2021, 2021.

Campins, J. and Navascués, B. Impact of targeted observations on HIRLAM forecasts during HyMeX-SOP1, Q. J. Roy. Meteor. Soc., 142, 363-376, https://doi.org/10.1002/qj.2737, 2016.

Carrió, D. S., Homar, V., Jansà, A., Picornell, M. A., and Campins, J.: Diagnosis of a high-impact secondary cyclone during HyMeX-SOP1 IOP18, Atmos. Res., 242, 104983, https://doi.org/10.1016/j.atmosres.2020.104983, 2020.

Cavaleri, L., Bajo, M., Barbariol, F., Bastianini, M., Benetazzo, A., Bertotti, L., Chiggiato, J., Davolio, S., Ferrarin, C., Magnusson, L., Papa, A., Pezzutto, P., Pomaro, A., and Umgiesser, G.: The October 29, 2018 storm in Northern Italy - An exceptional event and its modeling, Progr. Oceanogr., 178, 102178, https://doi.org/10.1016/j.pocean.2019.102178, 2019.

Chazette, P., Flamant, C., Raut, J.-C., Totems, J., and Shang, X.: Tropical moisture enriched storm tracks over the Mediterranean and their link with intense rainfall in the Cevennes-Vivarais area during HyMeX, Q. J. Roy. Meteor. Soc., 142, 320-334, https://doi.org/10.1002/qj.2674, 2015a.

Chazette, P., Flamant, C., Shang, X., Totems, J., Raut, J.-C., Doerenbecher, A., Ducrocq, V., Fourrié, N., Bock, O., and Cloché, S.: A multi-instrument and multi-model assessment of atmospheric moisture variability over the western Mediter- 
ranean during HyMeX, Q. J. Roy. Meteor. Soc., 142, 7-22, https://doi.org/10.1002/qj.2671, 2015 b.

Chazette, P., Totems, J., Ancellet, G., Pelon, J., and Sicard, M.: Temporal consistency of lidar observations during aerosol transport events in the framework of the ChArMEx/ADRIMED campaign at Minorca in June 2013, Atmos. Chem. Phys., 16, 28632875, https://doi.org/10.5194/acp-16-2863-2016, 2016.

Clark, P., Roberts, N., Lean, H., Ballard, S. P., and CharltonPerez, C.: Convection-permitting models: a step-change in rainfall forecasting, Meteorol. Appl., 23, 165-181, https://doi.org/10.1002/met.1538, 2016.

Colmet-Daage, A., Sanchez-Gomez, E., Ricci, S., Llovel, C., Borrell Estupina, V., Quintana-Seguí, P., Llasat, M. C., and Servat, E.: Evaluation of uncertainties in mean and extreme precipitation under climate change for northwestern Mediterranean watersheds from high-resolution Med and EuroCORDEX ensembles, Hydrol. Earth Syst. Sci., 22, 673-687, https://doi.org/10.5194/hess-22-673-2018, 2018.

Coppola, E., Sobolowski, S., Pichelli, E., Raffaele, F., Ahrens, B., Anders, I., Ban, N., Bastin, S., Belda, M., Belusic, D., CaldasAlvarez, A., Cardoso, R. M., Davolio, S., Dobler, A., Fernandez, J., Fita, L., Fumiere, Q., Giorgi, F., Goergen, K., Güttler, I., Halenka, T., Heinzeller, D., Hodnebrog, Ø., Jacob, D., Kartsios, S., Katragkou, E., Kendon, E., Khodayar, S., Kunstmann, H., Knist, S., Laviìn-Gullón, A., Lind, P., Lorenz, T., Maraun, D., Marelle, L., van Meijgaard, E., Milovac, J., Myhre, G., Panitz, H.-J., Piazza, M., Raffa, M., Raub, T., Rockel, B., Schär, C., Sieck, K., Soares, P. M. M., Somot, S., Srnec, L., Stocchi, P., Tölle, M. H., Truhetz, H., Vautard, R., de Vries, H., and Warrach-Sagi, K.: A first-of-its-kind multi-model convection permitting ensemble for investigating convective phenomena over Europe and the Mediterranean, Clim. Dynam., 55, 3-34, https://doi.org/10.1007/s00382-018-4521-8, 2018.

Corsmeier, U., Hankers, R., and Wieser, A.: Airborne turbulence measurements in the lower troposphere onboard the research aircraft Dornier 128-6, D-IBUF, Meteorol. Z., 10,, 315-329, https://doi.org/10.1127/0941-2948/2001/0010-0315, 2001.

Davolio, S., Mastrangelo, D., Miglietta, M. M., Drofa, O., Buzzi, A., and Malguzzi, P.: High resolution simulations of a flash flood near Venice, Nat. Hazards Earth Syst. Sci., 9, 1671-1678, https://doi.org/10.5194/nhess-9-1671-2009, 2009.

Davolio, S., Miglietta, M. M., Diomede, T., Marsigli, C., and Montani, A.: A flood episode in northern Italy: multi-model and single-model mesoscale meteorological ensembles for hydrological predictions, Hydrol. Earth Syst. Sci., 17, 2107-2120, https://doi.org/10.5194/hess-17-2107-2013, 2013.

Davolio, S., Silvestro, F., and Malguzzi, P.: Effects of Increasing Horizontal Resolution in a Convection-Permitting Model on Flood Forecasting: The 2011 Dramatic Events in Liguria, Italy, J. Hydrometeorol., 16, 1843-1856, https://doi.org/10.1175/jhmd-14-0094.1, 2015.

Davolio, S., Henin, R., Stocchi, P., and Buzzi, A.: Bora wind and heavy persistent precipitation: atmospheric water balance and role of air-sea fluxes over the Adriatic Sea, Q. J. Roy. Meteor. Soc., 143, 1165-1177, https://doi.org/10.1002/qj.3002, 2017.

Davolio, S., Della Fera, S., Laviola, S., Miglietta, M. M., and Levizzani, V.: Heavy Precipitation over Italy from the Mediterranean Storm" in October 2018: Assessing the Role of an
Atmospheric River, Mon. Weather Rev., 148, 3571-3588, https://doi.org/10.1175/mwr-d-20-0021.1, 2020.

Dayan, U., Nissen, K., and Ulbrich, U.: Review Article: Atmospheric conditions inducing extreme precipitation over the eastern and western Mediterranean, Nat. Hazards Earth Syst. Sci., 15, 2525-2544, https://doi.org/10.5194/nhess-15-2525-2015, 2015.

Defer, E., Pinty, J.-P., Coquillat, S., Martin, J.-M., Prieur, S., Soula, S., Richard, E., Rison, W., Krehbiel, P., Thomas, R., Rodeheffer, D., Vergeiner, C., Malaterre, F., Pedeboy, S., Schulz, W., Farges, T., Gallin, L.-J., Ortéga, P., Ribaud, J.-F., Anderson, G., Betz, H.-D., Meneux, B., Kotroni, V., Lagouvardos, K., Roos, S., Ducrocq, V., Roussot, O., Labatut, L., and Molinié, G.: An overview of the lightning and atmospheric electricity observations collected in southern France during the HYdrological cycle in Mediterranean EXperiment (HyMeX), Special Observation Period 1, Atmos. Meas. Tech., 8, 649-669, https://doi.org/10.5194/amt-8-649-2015, 2015.

de Vries, A. J.: A global climatological perspective on the importance of Rossby wave breaking and intense moisture transport for extreme precipitation events, Weather Clim. Dynam., 2, 129161, https://doi.org/10.5194/wcd-2-129-2021, 2021.

Di Girolamo, P., Summa, D., Lin, R.-F., Maestri, T., Rizzi, R., and Masiello, G.: UV Raman lidar measurements of relative humidity for the characterization of cirrus cloud microphysical properties, Atmos. Chem. Phys., 9, 8799-8811, https://doi.org/10.5194/acp9-8799-2009, 2009.

Di Girolamo, P., Flamant, C., Cacciani, M., Summa, D., Stelitano, D., Richard, E., Ducrocq, V., Fourrie, N. and Said, F.: Lidar observations of low-level wind reversals over the Gulf of Lion and characterization of their impact on the water vapour variability, International Radiation Symposium (IRC/IAMAS), Apr 2016, Auckland, New Zealand, 080001, https://doi.org/10.1063/1.4975532, insu-01501821, 2017.

Diomede, T., Marsigli, C., Montani, A., Nerozzi, F., and Paccagnella, T.: Calibration of Limited-Area Ensemble Precipitation Forecasts for Hydrological Predictions, Mon. Weather Rev., 142, 2176-2197, https://doi.org/10.1175/mwr-d13-00071.1, 2014.

Doerenbecher, A., Basdevant, C., Drobinski, P., Durand, P., Fesquet, C., Bernard, F., Cocquerez, P., Verdier, N., and Vargas, A.: LowAtmosphere Drifting Balloons: Platforms for Environment Monitoring and Forecast Improvement, B. Am. Meteorol. Soc., 97, 1583-1599, https://doi.org/10.1175/bams-d-14-00182.1, 2016.

Doocy, S., Daniels, A., Murray, S., and Kirsch, T. D.: The Human Impact of Floods: a Historical Review of Events 1980-2009 and Systematic Literature Review, PLoS Currents, 2013.

Draxler, R. R. and Hess, G. D.: An overview of the HYSPLIT_4 modelling system for trajectories, dispersion and deposition, Aust. Met. Mag., 47, 295-308, 1998.

Drobinski, P., Ducrocq, V., Alpert, P., Anagnostou, E., Béranger, K., Borga, M., Braud, I., Chanzy, A., Davolio, S., Delrieu, G., Estournel, C., Boubrahmi, N. F., Font, J., Grubišić, V., Gualdi, S., Homar, V., Ivančan-Picek, B., Kottmeier, C., Kotroni, V., Lagouvardos, K., Lionello, P., Llasat, M. C., Ludwig, W., Lutoff, C., Mariotti, A., Richard, E., Romero, R., Rotunno, R., Roussot, O., Ruin, I., Somot, S., Taupier-Letage, I., Tintore, J., Uijlenhoet, R., and Wernli, H.: HyMeX: A 10-Year Multidisciplinary Program on the Mediterranean Water Cycle, B. Am. Meteorol. Soc., 95, 1063-1082, https://doi.org/10.1175/bams-d-12-00242.1, 2014. 
Drobinski, P., Silva, N. D., Panthou, G., Bastin, S., Muller, C., Ahrens, B., Borga, M., Conte, D., Fosser, G., Giorgi, F., Güttler, I., Kotroni, V., Li, L., Morin, E., Önol, B., Quintana-Segui, P., Romera, R., and Torma, C. Z.: Scaling precipitation extremes with temperature in the Mediterranean: past climate assessment and projection in anthropogenic scenarios, Clim. Dynam., 51, 1237-1257, https://doi.org/10.1007/s00382-016-3083-x, 2016.

Ducrocq, V., Nuissier, O., Ricard, D., Lebeaupin, C., and Thouvenin, T.: A numerical study of three catastrophic precipitating events over southern France. II: Mesoscale triggering and stationarity factors, Q. J. Roy. Meteor. Soc., 134, 131-145, https://doi.org/10.1002/qj.199, 2008.

Ducrocq, V., Braud, I., Davolio, S., Ferretti, R., Flamant, C., Jansa, A., Kalthoff, N., Richard, E., Taupier-Letage, I., Ayral, P.-A., Belamari, S., Berne, A., Borga, M., Boudevillain, B., Bock, O., Boichard, J.-L., Bouin, M.-N., Bousquet, O., Bouvier, C., Chiggiato, J., Cimini, D., Corsmeier, U., Coppola, L., Cocquerez, P., Defer, E., Delanoë, J., Girolamo, P. D., Doerenbecher, A., Drobinski, P., Dufournet, Y., Fourrié, N., Gourley, J. J., Labatut, L., Lambert, D., Coz, J. L., Marzano, F. S., Molinié, G., Montani, A., Nord, G., Nuret, M., Ramage, K., Rison, W., Roussot, O., Said, F., Schwarzenboeck, A., Testor, P., Baelen, J. V., Vincendon, B., Aran, M. and Tamayo, J.: HyMeX-SOP1: The Field Campaign Dedicated to Heavy Precipitation and Flash Flooding in the Northwestern Mediterranean, B. Am. Meteorol. Soc., 95, 1083-1100, https://doi.org/10.1175/bams-d-12-00244.1, 2014.

Duffourg, F. and Ducrocq, V.: Origin of the moisture feeding the Heavy Precipitating Systems over Southeastern France, Nat. Hazards Earth Syst. Sci., 11, 1163-1178, https://doi.org/10.5194/nhess-11-1163-2011, 2011.

Duffourg, F. and Ducrocq, V.: Assessment of the water supply to Mediterranean heavy precipitation: a method based on finely designed water budgets, Atmos. Sci. Lett., 14, 133-138, https://doi.org/10.1002/asl2.429, 2013.

Duffourg, F., Nuissier, O., Ducrocq, V., Flamant, C., Chazette, P., Delanoë, J., Doerenbecher, A., Fourrié, N., Girolamo, P. D., Lac, C., Legain, D., Martinet, M., Saïd, F., and Bock, O.: Offshore deep convection initiation and maintenance during the HyMeX IOP 16a heavy precipitation event, Q. J. Roy. Meteor. Soc., 142, 259-274, https://doi.org/10.1002/qj.2725, 2016.

Duffourg, F., Lee, K.-O., Ducrocq, V., Flamant, C., Chazette, P., and Girolamo, P. D.: Role of moisture patterns in the backbuilding formation of HyMeX IOP13 heavy precipitation systems, Q. J. Roy. Meteor. Soc., 144, 291-303, https://doi.org/10.1002/qj.3201, 2018.

Eckhardt, S., Stohl, A., Wernli, H., James, P., Forster, C., and Spichtinger, N.: A 15-Year Climatology of Warm Conveyor Belts, J. Climate, 17, 218-237, 2004

Edouard, S., Vincendon, B., and Ducrocq, V.: Ensemble-based flash-flood modelling: Taking into account hydrodynamic parameters and initial soil moisture uncertainties, J. Hydrol., 560, 480-494, https://doi.org/10.1016/j.jhydrol.2017.04.048, 2018.

Federico, S., Torcasio, R. C., Avolio, E., Caumont, O., Montopoli, M., Baldini, L., Vulpiani, G., and Dietrich, S.: The impact of lightning and radar reflectivity factor data assimilation on the very short-term rainfall forecasts of RAMS@ISAC: application to two case studies in Italy, Nat. Hazards Earth Syst. Sci., 19, 1839-1864, https://doi.org/10.5194/nhess-19-1839-2019, 2019.
Fiori, E., Ferraris, L., Molini, L., Siccardi, F., Kranzlmueller, D., and Parodi, A.: Triggering and evolution of a deep convective system in the Mediterranean Sea: modelling and observations at a very fine scale, Q. J. Roy. Meteor. Soc., 143, 927-941, https://doi.org/10.1002/qj.2977, 2017.

Ferretti, R., Pichelli, E., Gentile, S., Maiello, I., Cimini, D., Davolio, S., Miglietta, M. M., Panegrossi, G., Baldini, L., Pasi, F., Marzano, F. S., Zinzi, A., Mariani, S., Casaioli, M., Bartolini, G., Loglisci, N., Montani, A., Marsigli, C., Manzato, A., Pucillo, A., Ferrario, M. E., Colaiuda, V., and Rotunno, R.: Overview of the first HyMeX Special Observation Period over Italy: observations and model results, Hydrol. Earth Syst. Sci., 18, 1953-1977, https://doi.org/10.5194/hess-18-1953-2014, 2014.

Flaounas, E., Raveh-Rubin, S., Wernli, H., Drobinski, P.m and Bastin, S.: The dynamical structure of intense Mediterranean cyclones, Clim. Dynam., 44, 2411-2427, https://doi.org/10.1007/s00382-014-2330-2, 2014.

Flaounas, E., Lagouvardos, K., Kotroni, V., Claud, C., Delanoë, J., Flamant, C., Madonna, E., and Wernli, H.: Processes leading to heavy precipitation associated with two Mediterranean cyclones observed during the HyMeX SOP1: Heavy Rainfall Associated with Two Cyclones during the HyMeX SOP1, Q. J. Roy. Meteor. Soc., 142, 275-286, https://doi.org/10.1002/qj.2618, 2016.

Flaounas, E., Luca, A. D., Drobinski, P., Mailler, S., Arsouze, T., Bastin, S., Beranger, K. and Brossier, C. L.: Cyclone contribution to the Mediterranean Sea water budget, Clim. Dynam., 46, 913 927, https://doi.org/10.1007/s00382-015-2622-1, 2015.

Flaounas, E., Kotroni, V., Lagouvardos, K., Gray, S. L., Rysman, J.-F., and Claud, C.: Heavy rainfall in Mediterranean cyclones. Part I: contribution of deep convection and warm conveyor belt, Clim. Dynam., 50, 2935-2949, https://doi.org/10.1007/s00382017-3783-x, 2018.

Flaounas, E., Fita, L., Lagouvardos, K., and Kotroni, V.: Heavy rainfall in Mediterranean cyclones, Part II: Water budget, precipitation efficiency and remote water sources, Clim. Dynam., 53, 2539-2555, https://doi.org/10.1007/s00382-019-04639-x, 2019.

Fosser, G., Khodayar, S., and Berg, P.: Benefit of convection permitting climate model simulations in the representation of convective precipitation, Clim. Dynam., 44, 45-60, https://doi.org/10.1007/s00382-014-2242-1, 2014.

Fourrié, N., Bresson, É., Nuret, M., Jany, C., Brousseau, P., Doerenbecher, A., Kreitz, M., Nuissier, O., Sevault, E., Bénichou, H., Amodei, M., and Pouponneau, F.: AROME-WMED, a real-time mesoscale model designed for the HyMeX special observation periods, Geosci. Model Dev., 8, 1919-1941, https://doi.org/10.5194/gmd-8-1919-2015, 2015.

Fourrié, N., Nuret, M., Brousseau, P., Caumont, O., Doerenbecher, A., Wattrelot, E., Moll, P., Bénichou, H., Puech, D., Bock, O., Bosser, P., Chazette, P., Flamant, C., Di Girolamo, P., Richard, E., and Saïd, F.: The AROME-WMED reanalyses of the first special observation period of the Hydrological cycle in the Mediterranean experiment (HyMeX), Geosci. Model Dev., 12, 2657 2678, https://doi.org/10.5194/gmd-12-2657-2019, 2019.

Fourrié, N., Nuret, M., Brousseau, P., and Caumont, O.: Data assimilation impact studies with the AROME-WMED reanalysis of the first special observation period of the Hydrological cycle in the Mediterranean Experiment, Nat. Hazards Earth Syst. Sci. 21, 463-480, https://doi.org/10.5194/nhess-21-463-2021, 2021. 
Fresnay, S., Hally, A., Garnaud, C., Richard, E., and Lambert, D.: Heavy precipitation events in the Mediterranean: sensitivity to cloud physics parameterisation uncertainties, Nat. Hazards Earth Syst. Sci., 12, 2671-2688, https://doi.org/10.5194/nhess12-2671-2012, 2012.

Fumière, Q., Déqué, M., Nuissier, O., Somot, S., Alias, A., Caillaud, C., Laurantin, O., and Seity, Y.: Extreme rainfall in Mediterranean France during the fall: added value of the CNRMAROME Convection-Permitting Regional Climate Model, Clim. Dynam., 55, 77-91, https://doi.org/10.1007/s00382-019-048988, 2019.

Funatsu, B. M., Claud, C., and Chaboureau, J.-P.: A 6-year AMSUbased climatology of upper-level troughs and associated precipitation distribution in the Mediterranean region, J. Geophys. Res., 113, D15120, https://doi.org/10.1029/2008jd009918, 2008.

Galanaki, E., Flaounas, E., Kotroni, V., Lagouvardos, K., and Argiriou, A.: Lightning activity in the Mediterranean: quantification of cyclones contribution and relation to their intensity, Atmos. Sci. Lett., 17, 510-516, https://doi.org/10.1002/asl.685, 2016.

Gao, X., Pal, J. S., and Giorgi, F.: Projected changes in mean and extreme precipitation over the Mediterranean region from a high resolution double nested RCM simulation, Geophys. Res. Lett., 33, L03706, https://doi.org/10.1029/2005g1024954, 2006.

Giorgi, F.: Climate change hot-spots, Geophys. Res. Lett., 33, L08707, https://doi.org/10.1029/2006gl025734, 2006.

Giorgi, F., Raffaele, F., and Coppola, E.: The response of precipitation characteristics to global warming from climate projections, Earth Syst. Dynam., 10, 73-89, https://doi.org/10.5194/esd-1073-2019, 2019.

Giovannini, L., Davolio, S., Zaramella, M., Zardi, D., and Borga, M.: Multi-model convection-resolving simulations of the October 2018 Vaia storm over Northeastern Italy, Atmos. Res., 253, 105455, https://doi.org/10.1016/j.atmosres.2021.105455, 2021.

Gires, A., Tchiguirinskaia, I., Schertzer, D., and Berne, A.: 2DVD Data Revisited: Multifractal Insights into Cuts of the Spatiotemporal Rainfall Process, J. Hydrometeorol., 16, 548-562, https://doi.org/10.1175/jhm-d-14-0127.1, 2015.

Grams, C. M., Wernli, H., Böttcher, M., Čampa, J., Corsmeier, U., Jones, S. C., Keller, J. H., Lenz, C.-J., and Wiegand, L.: The key role of diabatic processes in modifying the upper-tropospheric wave guide: a North Atlantic case-study, Q. J. Roy. Meteor. Soc., 137, 2174-2193, https://doi.org/10.1002/qj.891, 2011.

Grazioli, J., Tuia, D., and Berne, A.: Hydrometeor classification from polarimetric radar measurements: a clustering approach, Atmos. Meas. Tech., 8, 149-170, https://doi.org/10.5194/amt-8149-2015, 2015.

Grazzini, F., Craig, G. C., Keil, C., Antolini, G., and Pavan, V.: Extreme precipitation events over northern Italy. Part I: A systematic classification with machine-learning techniques, Q. J. Roy. Meteor. Soc., 146, 69-85, https://doi.org/10.1002/qj.3635, 2019.

Grazzini, F., Fragkoulidis, G., Teubler, F., Wirth, V., and Craig, G. C.: Extreme precipitation events over northern Italy. Part II: Dynamical precursors, Q. J. Roy. Meteor. Soc., 147, 1237-1257, https://doi.org/10.1002/qj.3969, 2021.

Hachani, S., Boudevillain, B., Delrieu, G., and Bargaoui, Z.: Drop Size Distribution Climatology in Cévennes-Vivarais Region, France, Atmosphere, 8, 233, https://doi.org/10.3390/atmos8120233, 2017.
Hally, A., Richard, E., and Ducrocq, V.: An ensemble study of HyMeX IOP6 and IOP7a: sensitivity to physical and initial and boundary condition uncertainties, Nat. Hazards Earth Syst. Sci., 14, 1071-1084, https://doi.org/10.5194/nhess-141071-2014, 2014.

Hally, A., Caumont, O., Garrote, L., Richard, E., Weerts, A., Delogu, F., Fiori, E., Rebora, N., Parodi, A., Mihalović, A., Ivković, M., Dekić, L., van Verseveld, W., Nuissier, O., Ducrocq, V., D'Agostino, D., Galizia, A., Danovaro, E., and Clematis, A.: Hydrometeorological multi-model ensemble simulations of the 4 November 2011 flash flood event in Genoa, Italy, in the framework of the DRIHM project, Nat. Hazards Earth Syst. Sci., 15, 537-555, https://doi.org/10.5194/nhess-15-537-2015, 2015.

Hawcroft, M. K., Shaffrey, L. C., Hodges, K. I., and Dacre, H. F.: How much Northern Hemisphere precipitation is associated with extratropical cyclones?, Geophys. Res. Lett., 39, L24809, https://doi.org/10.1029/2012g1053866, 2012.

Helgert, S. and Khodayar, S.: Improvement of the soil-atmosphere interactions and subsequent heavy precipitation modelling by enhanced initialization using remotely sensed $1 \mathrm{~km}$ soil moisture information, Remote Sens. Environ., 246, 111812 , https://doi.org/10.1016/j.rse.2020.111812, 2020.

Hertig, E., Tramblay, Y., Romberg, K., Kaspar-Ott, I., and Merkenschlager, C.: The impact of soil moisture on precipitation downscaling in the Euro-Mediterranean area, Clim. Dynam., 52, 2869-2884, https://doi.org/10.1007/s00382-018-4304-2, 2018.

Homar, V., Ramis, C., Romero, R., Alonso, S., Garcia-Moya, J. A., and Alarcon, M.: A Case of Convection Development over the Western Mediterranean Sea: A Study through $\mathrm{Nu}-$ merical Simulations, Meteorol. Atmos. Phys., 71, 169-188, https://doi.org/10.1007/s007030050054, 1999.

Insua-Costa, D., Miguez-Macho, G., and Llasat, M. C.: Local and remote moisture sources for extreme precipitation: a study of the two catastrophic 1982 western Mediterranean episodes, Hydrol. Earth Syst. Sci., 23, 3885-3900, https://doi.org/10.5194/hess-233885-2019, 2019.

IPCC: Climate Change 2013: The Physical Science Basis, Contribution of Working Group I to the Fifth Assessment Report of the Intergovernmental Panel on Climate Change, edited by: Stocker, T. F., Qin, D., Plattner,G.-K., Tignor, M., Allen, S. K., Boschung, J., Nauels, A., Xia, Y., Bex, V., and Midgley, P. M., Intergovernmental Panel on Climate Change, Cambridge University Press, 2009.

Jacob, D., Petersen, J., Eggert, B., Alias, A., Christensen, O. B., Bouwer, L. M., Braun, A., Colette, A., Déqué, M., Georgievski, G., Georgopoulou, E., Gobiet, A., Menut, L., Nikulin, G., Haensler, A., Hempelmann, N., Jones, C., Keuler, K., Kovats, S., Kröner, N., Kotlarski, S., Kriegsmann, A., Martin, E., van Meijgaard, E., Moseley, C., Pfeifer, S., Preuschmann, S., Radermacher, C., Radtke, K., Rechid, D., Rounsevell, M., Samuelsson, P., Somot, S., Soussana, J.-F., Teichmann, C., Valentini, R., Vautard, R., Weber, B., and Yiou, P.: EURO-CORDEX: new high-resolution climate change projections for European impact research, Regional Environmental Change, 14, 563-578, https://doi.org/10.1007/s10113-013-0499-2, 2013.

Jansa, A., Genoves, A., Picornell, M. A., Campins, J., Riosalido, R., and Carretero, O.: Western Mediterranean cyclones and heavy rain. Part 2: Statistical approach, Meteorol. Appl., 8, 43-56, https://doi.org/10.1017/s1350482701001049, 2001. 
Jansa, A., Campins, J., Picornell, M. A., and Guijarro, J.: Heavy rain and strong wind events over Spain during HyMeX SOP1, Tethys, 11, 25-38, https://doi.org/10.3369/tethys.2014.11.03, 2014.

Jianyun, G., Ziwang, D., and Xiaolan, Z.: Spatial/temporal features of drought/flood in Fujian for the past 4 decades, J. Trop. Meteorol., 22, 491-497, 2006.

Kagkara, C., Wobrock, W., Planche, C., and Flossmann, A. I.: The sensitivity of intense rainfall to aerosol particle loading - a comparison of bin-resolved microphysics modelling with observations of heavy precipitation from HyMeX IOP7a, Nat. Hazards Earth Syst. Sci., 20, 1469-1483, https://doi.org/10.5194/nhess20-1469-2020, 2020.

Kalthoff, N., Adler, B., Wieser, A., Kohler, M., Träumner, K., Handwerker, J., Corsmeier, U., Khodayar, S., Lambert, D., Kopmann, A., Kunka, N., Dick, G., Ramatschi, M., Wickert, J., and Kottmeier, C.: KITcube a mobile observation platform for convection studies deployed during HyMeX, Meteorol. Z., 22, 633647, https://doi.org/10.1127/0941-2948/2013/0542, 2013.

Khodayar, S., Czajka, B., Caldas-Alvarez, A., Helgert, S., Flamant, C., Girolamo, P. D., Bock, O., and Chazette, P.: Multi-scale observations of atmospheric moisture variability in relation to heavy precipitating systems in the northwestern Mediterranean during HyMeX IOP12, Q. J. Roy. Meteor. Soc., 144, 2761-2780, https://doi.org/10.1002/qj.3402, 2018.

Khodayar, S., Fosser, G., Berthou, S., Davolio, S., Drobinski, P., Ducrocq, V., Ferretti, R., Nuret, M., Pichelli, E., Richard, E., and Bock, O.: A seamless weather-climate multi-model intercomparison on the representation of a high impact weather event in the western Mediterranean: HyMeX IOP12, Q. J. Roy. Meteor. Soc., 142, 433-452, https://doi.org/10.1002/qj.2700, 2016a.

Khodayar, S., Kalthoff, N., and Kottmeier, C.: Atmospheric conditions associated with heavy precipitation events in comparison to seasonal means in the western mediterranean region, Clim. Dynam., 51, 951-967, https://doi.org/10.1007/s00382-016-3058-y, 2016b.

Khodayar, S., Raff, F., Kalthoff, N., and Bock, O.: Diagnostic study of a high-precipitation event in the Western Mediterranean: adequacy of current operational networks, Q. J. Roy. Meteor. Soc., 142, 72-85, https://doi.org/10.1002/qj.2600, 2015.

Kirshbaum, D. J., Adler, B., Kalthoff, N., Barthlott, C., and Serafin S.: Moist orographic convection: Physical mechanisms and links to surface-exchange processes, Atmosphere, 9, 80, https://doi.org/10.3390/atmos9030080, 2018.

Krichak, S. O., Feldstein, S. B., Alpert, P., Gualdi, S., Scoccimarro, E., and Yano, J.-I.: Discussing the role of tropical and subtropical moisture sources in cold season extreme precipitation events in the Mediterranean region from a climate change perspective, Nat. Hazards Earth Syst. Sci., 16, 269-285, https://doi.org/10.5194/nhess-16-269-2016, 2016.

Lebeaupin, C., Ducrocq, V., and Giordani, H.: Sensitivity of torrential rain events to the sea surface temperature based on highresolution numerical forecasts, J. Geophys. Res., 111, D12110, https://doi.org/10.1029/2005jd006541, 2006.

Lebeaupin-Brossier, C., Bastin, S., Béranger, K., and Drobinski, P.: Regional mesoscale air-sea coupling impacts and extreme meteorological events role on the Mediterranean Sea water budget, Clim. Dynam., 44, 1029-1051, https://doi.org/10.1007/s00382014-2252-z, 2014.
Lee, K.-O., Flamant, C., Ducrocq, V., Duffourg, F., Fourrié, N., and Davolio, S.: Convective initiation and maintenance processes of two back-building mesoscale convective systems leading to heavy precipitation events in Southern Italy during HyMeX IOP 13, Q. J. Roy. Meteor. Soc., 142, 2623-2635, https://doi.org/10.1002/qj.2851, 2016.

Lee, K.-O., Flamant, C., Ducrocq, V., Duffourg, F., Fourrié, N., Delanoë, J., and Bech, J.: Initiation and development of a mesoscale convective system in the Ebro River Valley and related heavy precipitation over northeastern Spain during HyMeX IOP 15a, Q. J. Roy. Meteor. Soc., 143, 942-956, https://doi.org/10.1002/qj.2978, 2017.

Lee, K.-O., Flamant, C., Duffourg, F., Ducrocq, V., and Chaboureau, J.-P.: Impact of upstream moisture structure on a back-building convective precipitation system in south-eastern France during HyMeX IOP13, Atmos. Chem. Phys., 18, 1684516862, https://doi.org/10.5194/acp-18-16845-2018, 2018.

Lee, K.-O., Aemisegger, F., Pfahl, S., Flamant, C., Lacour, J.-L., and Chaboureau, J.-P.: Contrasting stable water isotope signals from convective and large-scale precipitation phases of a heavy precipitation event in southern Italy during HyMeX IOP 13: a modelling perspective, Atmos. Chem. Phys., 19, 7487-7506, https://doi.org/10.5194/acp-19-7487-2019, 2019.

Lindskog, M., Ridal, M., Thorsteinsson, S., and Ning, T.: Data assimilation of GNSS zenith total delays from a Nordic processing centre, Atmos. Chem. Phys., 17, 13983-13998, https://doi.org/10.5194/acp-17-13983-2017, 2017.

Llasat, M. C., Llasat-Botija, M., Prat, M. A., Porcú, F., Price, C., Mugnai, A., Lagouvardos, K., Kotroni, V., Katsanos, D., Michaelides, S., Yair, Y., Savvidou, K., and Nicolaides, K.: High-impact floods and flash floods in Mediterranean countries: the FLASH preliminary database, Adv. Geosci., 23, 47-55, https://doi.org/10.5194/adgeo-23-47-2010, 2010.

Lovat, A., Vincendon, B., and Ducrocq, V.: Assessing the impact of resolution and soil datasets on flash-flood modelling, Hydrol. Earth Syst. Sci., 23, 1801-1818, https://doi.org/10.5194/hess-231801-2019, 2019.

Madonna, E., Wernli, H., Joos, H., and Martius, O.: Warm conveyor belts in the ERA-Interim dataset (1979-2010). Part I: Climatology and potential vorticity evolution, J. Climate, 27, 3-26, https://doi.org/10.1175/jcli-d-12-00720.1, 2014.

Magnusson, L., Hewson, T., and Lavers, D.: Windstorm Alex affected large parts of Europe, ECMWF Newsletter, 166, 4-5, 2021.

Maiello, I., Gentile, S., Ferretti, R., Baldini, L., Roberto, N., Picciotti, E., Alberoni, P. P., and Marzano, F. S.: Impact of multiple radar reflectivity data assimilation on the numerical simulation of a flash flood event during the HyMeX campaign, Hydrol. Earth Syst. Sci., 21, 5459-5476, https://doi.org/10.5194/hess-21-54592017, 2017.

Manzato, A., Davolio, S., Miglietta, M. M., Pucillo, A., and Setvák, M.: 12 September 2012: A supercell outbreak in NE Italy?, Atmos. Res., 153, 98-118, https://doi.org/10.1016/j.atmosres.2014.07.019, 2015.

Mariotti, A.: Recent Changes in the Mediterranean Water Cycle: A Pathway toward Long-Term Regional Hydroclimatic Change?, J. Climate, 23, 1513-1525, https://doi.org/10.1175/2009jcli3251.1, 2010. 
Marsigli, C., Montani, A., and Paccagnella, T.: Provision of boundary conditions for a convection-permitting ensemble: comparison of two different approaches, Nonlin. Processes Geophys., 21, 393-403, https://doi.org/10.5194/npg-21-393-2014, 2014.

Martinet, M., Nuissier, O., Duffourg, F., Ducrocq, V., and Ricard, D.: Fine-scale numerical analysis of the sensitivity of the HyMeX IOP16a heavy precipitating event to the turbulent mixing-length parametrization, Q. J. Roy. Meteor. Soc., 143, 3122-3135, https://doi.org/10.1002/qj.3167, 2017.

Mastrantonas, N., Herrera-Lormendez, P., Magnusson, L., Pappenberger, F., and Matschullat, J.: Extreme precipitation events in the Mediterranean: Spatiotemporal characteristics and connection to large-scale atmospheric flow patterns, Int. J. Climatol., 41, 27102728, https://doi.org/10.1002/joc.6985, 2021.

Meroni, A. N., Parodi, A., and Pasquero, C.: Role of SST Patterns on Surface Wind Modulation of a Heavy Midlatitude Precipitation Event, J. Geophys. Res.-Atmos., 123, 9081-9096, https://doi.org/10.1029/2018jd028276, 2018a.

Meroni, A. N., Renault, L., Parodi, A., and Pasquero, C.: Role of the Oceanic Vertical Thermal Structure in the Modulation of Heavy Precipitations Over the Ligurian Sea, Pure Appl. Geophys., 175, 4111-4130, https://doi.org/10.1007/s00024-018-2002-y, 2018b.

Miglietta, M. M. and Rotunno, R.: Numerical Simulations of Conditionally Unstable Flows over a Mountain Ridge, J. Atmos. Sci., 66, 1865-1885, https://doi.org/10.1175/2009jas2902.1, 2009.

Miglietta, M. M. and Rotunno, R.: Numerical Simulations of Sheared Conditionally Unstable Flows over a Mountain Ridge, J. Atmos. Sci., 71, 1747-1762, https://doi.org/10.1175/jas-d-130297.1, 2014.

Miglietta, M. M., Manzato, A., and Rotunno, R.: Characteristics and predictability of a supercell during HyMeX SOP1, Q. J. Roy. Meteor. Soc., 142, 2839-2853, https://doi.org/10.1002/qj.2872, 2016.

Moeng, C.-H., Sullivan, P. P., Khairoutdinov, M. F., and Randall, D. A.: A Mixed Scheme for Subgrid-Scale Fluxes in Cloud-Resolving Models, J. Atmos. Sci., 67, 3692-3705, https://doi.org/10.1175/2010jas3565.1, 2010.

Molinié, G., Ceresetti, D., Anquetin, S., Creutin, J. D., and Boudevillain, B.: Rainfall Regime of a Mountainous Mediterranean Region: Statistical Analysis at Short Time Steps, J. Appl. Meteorol. Climatol., 51, 429-448, https://doi.org/10.1175/2011jamc2691.1, 2012.

Nelson, G. C., Rosegrant, M. W., Palazzo, A., Gray, I., Ingersoll, C., Robertson, R., Tokgoz, S., Zhu, T., Sulser, T. B., Ringler, C., Msangi, S., and You, L.: Food Security, Farming, and Climate Change to 2050: Scenarios, Results, Policy Options, International Food Policy Research Institute, 2010.

Nielsen, E. R. and Schumacher, R. S.: Using ConvectionAllowing Ensembles to Understand the Predictability of an Extreme Rainfall Event, Mon. Weather Rev., 144, 3651-3676, https://doi.org/10.1175/mwr-d-16-0083.1, 2016.

Nuissier, O., Ducrocq, V., Ricard, D., Lebeaupin, C., and Anquetin, S.: A numerical study of three catastrophic precipitating events over southern France. I: Numerical framework and synoptic ingredients, Q. J. Roy. Meteor. Soc., 134, 111-130, https://doi.org/10.1002/qj.200, 2008.

Nuissier, O., Joly, B., Joly, A., Ducrocq, V., and Arbogast, P.: A statistical downscaling to identify the large-scale circulation patterns associated with heavy precipitation events over southern France, Q. J. Roy. Meteor. Soc., 137, 1812-1827, https://doi.org/10.1002/qj.866, 2011.

Nuissier, O., Joly, B., Vié, B., and Ducrocq, V.: Uncertainty of lateral boundary conditions in a convection-permitting ensemble: a strategy of selection for Mediterranean heavy precipitation events, Nat. Hazards Earth Syst. Sci., 12, 2993-3011, https://doi.org/10.5194/nhess-12-2993-2012, 2012.

Nuissier, O., Marsigli, C., Vincendon, B., Hally, A., Bouttier, F., Montani, A., and Paccagnella, T.: Evaluation of two convectionpermitting ensemble systems in the HyMeX Special Observation Period (SOP1) framework, Q. J. Roy. Meteor. Soc., 142, 404418, https://doi.org/10.1002/qj.2859, 2016.

Nuissier, O., Duffourg, F., Martinet, M., Ducrocq, V., and Lac, C.: Hectometric-scale simulations of a Mediterranean heavy-precipitation event during the Hydrological cycle in the Mediterranean Experiment (HyMeX) first Special Observation Period (SOP1), Atmos. Chem. Phys., 20, 14649-14667, https://doi.org/10.5194/acp-20-14649-2020, 2020.

Oertel, A., Boettcher, M., Joos, H., Sprenger, M., Konow, H., Hagen, M., and Wernli, H.: Convective activity in an extratropical cyclone and its warm conveyor belt - a casestudy combining observations and a convection-permitting model simulation, Q. J. Roy. Meteor. Soc., 145, 1406-1426, https://doi.org/10.1002/qj.3500, 2019.

Oost, W. A., Komen, G. J., Jacobs, C. M. J., and Oort, C. V.: New evidence for a relation between wind stress and wave age from measurements during ASGAMAGE, Bound.-Lay. Meteorol., 103, 409-438, https://doi.org/10.1023/a:1014913624535, 2002.

Orlowsky, B. and Seneviratne, S. I.: Global changes in extreme events: regional and seasonal dimension, Clim. Change, 110, 669-696, https://doi.org/10.1007/s10584-011-0122-9, 2011.

Papagiannaki, K., Kotroni, V., Lagouvardos, K., Ruin, I., and Bezes, A.: Urban Area Response to Flash Flood-Triggering Rainfall, Featuring Human Behavioral Factors: The Case of 22 October 2015 in Attica, Greece, Weather Clim. Soc., 9, 621-638, https://doi.org/10.1175/wcas-d-16-0068.1, 2017.

Pfahl, S., Madonna, E., Boettcher, M., Joos, H., and Wernli, H.: Warm Conveyor Belts in the ERA-Interim Dataset (1979-2010). Part II: Moisture Origin and Relevance for Precipitation, J. Climate, 27, 27-40, https://doi.org/10.1175/jcli-d-13-00223.1, 2014.

Pichelli, E., Rotunno, R., and Ferretti, R.: Effects of the Alps and Apennines on forecasts for Po Valley convection in two HyMeX cases, Q. J. Roy. Meteor. Soc., 143, 2420-2435, https://doi.org/10.1002/qj.3096, 2017.

Planton, S., Driouech, F., Rhaz, K. E., and Lionello, P.: The climate of the Mediterranean regions in the future climate projections, in: The Mediterranean region under climate change, ISBN 9780-12-416042-2, p. 86, 2016.

Poletti, M. L., Silvestro, F., Davolio, S., Pignone, F., and Rebora, N.: Using nowcasting technique and data assimilation in a meteorological model to improve very short range hydrological forecasts, Hydrol. Earth Syst. Sci., 23, 3823-3841, https://doi.org/10.5194/hess-23-3823-2019, 2019.

Prein, A. F., Langhans, W., Fosser, G., Ferrone, A., Ban, N., Goergen, K., Keller, M., Tölle, M., Gutjahr, O., Feser, F., Brisson, E., Kollet, S., Schmidli, J., Lipzig, N. P. M., and Leung, R.: A review on regional convection-permitting climate modeling: 
Demonstrations, prospects, and challenges, Rev. Geophys., 53, 323-361, https://doi.org/10.1002/2014rg000475, 2015.

Protat, A., Bouniol, D., Delanoë, J., O’Connor, E., May, P. T., Plana-Fattori, A., Hasson, A., Görsdorf, U., and Heymsfield, A. J.: Assessment of Cloudsat Reflectivity Measurements and Ice Cloud Properties Using Ground-Based and Airborne Cloud Radar Observations, J. Atmos. Ocean. Tech., 26, 1717-1741, https://doi.org/10.1175/2009jtecha1246.1, 2009.

Rainaud, R., Brossier, C. L., Ducrocq, V., Giordani, H., Nuret, M., Fourrié, N., Bouin, M.-N., Taupier-Letage, I., and Legain, D.: Characterization of air-sea exchanges over the Western Mediterranean Sea during HyMeX SOP1 using the AROMEWMED model, Q. J. Roy. Meteor. Soc., 142, 173-187, https://doi.org/10.1002/qj.2480, 2015.

Rainaud, R., Brossier, C. L., Ducrocq, V., and Giordani, H.: Highresolution air-sea coupling impact on two heavy precipitation events in the Western Mediterranean, Q. J. Roy. Meteor. Soc., 143, 2448-2462, https://doi.org/10.1002/qj.3098, 2017.

Ramis, C., Llasat, M. C., Genovés, A., and Jansà, A.: The October-1987 floods in Catalonia: Synoptic and mesoscale mechanisms, Met. Apps, 1, 337-350, https://doi.org/10.1002/met.5060010404, 1994.

Raupach, T. H. and Berne, A.: Small-Scale Variability of the Raindrop Size Distribution and Its Effect on Areal Rainfall Retrieval, J. Hydrometeorol., 17, 2077-2104, https://doi.org/10.1175/jhmd-15-0214.1, 2016.

Ravazzani, G., Amengual, A., Ceppi, A., Homar, V., Romero, R., Lombardi, G., and Mancini, M.: Potentialities of ensemble strategies for flood forecasting over the Milano urban area, J. Hydrology, 539, 237-253, https://doi.org/10.1016/j.jhydrol.2016.05.023, 2016.

Raveh-Rubin, S. and Flaounas, E.: A dynamical link between deep Atlantic extratropical cyclones and intense Mediterranean cyclones, Atmos. Sci. Lett., 18, 215-221, https://doi.org/10.1002/asl.745, 2017.

Raveh-Rubin, S. and Wernli, H.: Large-scale wind and precipitation extremes in the Mediterranean: a climatological analysis for 1979-2012, Q. J. Roy. Meteor. Soc., 141, 2404-2417, https://doi.org/10.1002/qj.2531, 2015.

Raynaud, L. and Bouttier, F.: Comparison of initial perturbation methods for ensemble prediction at convective scale, Q. J. Roy. Meteor. Soc., 142, 854-866, https://doi.org/10.1002/qj.2686, 2015.

Rebora, N., Molini, L., Casella, E., Comellas, A., Fiori, E., Pignone, F., Siccardi, F., Silvestro, F., Tanelli, S., and Parodi, A.: Extreme Rainfall in the Mediterranean: What Can We Learn from Observations?, J. Hydrometeorol., 14, 906-922, https://doi.org/10.1175/jhm-d-12-083.1, 2013.

Ribaud, J.-F., Bousquet, O., Coquillat, S., Al-Sakka, H., Lambert, D., Ducrocq, V., and Fontaine, E.: Evaluation and application of hydrometeor classification algorithm outputs inferred from multi-frequency dual-polarimetric radar observations collected during HyMeX, Q. J. Roy. Meteor. Soc., 142, 95-107, https://doi.org/10.1002/qj.2589, 2015.

Ribaud, J.-F., Bousquet, O., and Coquillat, S.: Relationships between total lightning activity, microphysics and kinematics during the 24 September 2012 HyMeX bow-echo system, Q. J. Roy. Meteor. Soc., 142, 298-309, https://doi.org/10.1002/qj.2756, 2016.
Ricard, D., Ducrocq, V., and Auger, L.: A Climatology of the Mesoscale Environment Associated with Heavily Precipitating Events over a Northwestern Mediterranean Area, J. Appl. Meteorol. Climatol., 51, 468-488, https://doi.org/10.1175/jamc-d-11017.1, 2012.

Richard, E., Buzzi, A., and Zängl, G.: Quantitative precipitation forecasting in the Alps: The advances achieved by the Mesoscale Alpine Programme, Q. J. Roy. Meteor. Soc., 133, 831-846, https://doi.org/10.1002/qj.65, 2007.

Röhner, L., Nerding, K.-U., and Corsmeier, U.: Diagnostic study of a HyMeX heavy precipitation event over Spain by investigation of moisture trajectories, Q. J. Roy. Meteor. Soc., 142, 287-297, https://doi.org/10.1002/qj.2825, 2016.

Rolph, G., Stein, A., and Stunder, B.: Real-time Environmental Applications and Display sYstem: READY, Environ. Model. Softw., 95, 210-228, https://doi.org/10.1016/j.envsoft.2017.06.025, 2017.

Romero, R., Ramis, C., and Homar, V.: On the severe convective storm of 29 October 2013 in the Balearic Islands: observational and numerical study, Q. J. Roy. Meteor. Soc., 141, 1208-1222, https://doi.org/10.1002/qj.2429, 2014.

Roux, H., Amengual, A., Romero, R., Bladé, E., and Sanz-Ramos, M.: Evaluation of two hydrometeorological ensemble strategies for flash-flood forecasting over a catchment of the eastern Pyrenees, Nat. Hazards Earth Syst. Sci., 20, 425-450, https://doi.org/10.5194/nhess-20-425-2020, 2020.

Ruin, I., Lutoff, C., Boudevillain, B., Creutin, J.-D., Anquetin, S., Rojo, M. B., Boissier, L., Bonnifait, L., Borga, M., ColbeauJustin, L., Creton-Cazanave, L., Delrieu, G., Douvinet, J., Gaume, E., Gruntfest, E., Naulin, J.-P., Payrastre, O., and Vannier, O.: Social and Hydrological Responses to Extreme Precipitations: An Interdisciplinary Strategy for Postflood Investigation, Weather, Clim. Soc., 6, 135-153, https://doi.org/10.1175/wcasd-13-00009.1, 2014.

Sauvage, C., Lebeaupin Brossier, C., Bouin, M.-N., and Ducrocq, V.: Characterization of the air-sea exchange mechanisms during a Mediterranean heavy precipitation event using realistic sea state modelling, Atmos. Chem. Phys., 20, 1675-1699, https://doi.org/10.5194/acp-20-1675-2020, 2020.

Scheffknecht, P., Richard, E., and Lambert, D.: A highly localized high-precipitation event over Corsica, Q. J. Roy. Meteor. Soc., 142, 206-221, https://doi.org/10.1002/qj.2795, 2016.

Scheffknecht, P., Richard, E., and Lambert, D.: Climatology of heavy precipitation over Corsica in the period 1985-2015, Q. J. Roy. Meteor. Soc., 143, 2987-2998, https://doi.org/10.1002/qj.3140, 2017.

Schleiss, M. and Smith, J.: A Method to Estimate the 3DTime Structure of the Raindrop Size Distribution Using Radar and Disdrometer Data, J. Hydrometeorol., 16, 1222-1242, https://doi.org/10.1175/jhm-d-14-0182.1, 2015.

Schumacher, R. S. and Johnson, R. H.: Organization and Environmental Properties of Extreme-Rain-Producing Mesoscale Convective Systems, Mon. Weather Rev., 133, 961-976, https://doi.org/10.1175/mwr2899.1, 2005.

Senatore, A., Davolio, S., Furnari, L., and Mendicino, G.: Reconstructing Flood Events in Mediterranean Coastal Areas Using Different Reanalyses and High-Resolution Meteorological Models, J. Hydrometeorol., 21, 1865-1887, https://doi.org/10.1175/jhm-d-19-0270.1, 2020a. 
Senatore, A., Furnari, L., and Mendicino, G.: Impact of highresolution sea surface temperature representation on the forecast of small Mediterranean catchments' hydrological responses to heavy precipitation, Hydrol. Earth Syst. Sci., 24, 269-291, https://doi.org/10.5194/hess-24-269-2020, 2020b.

Seyfried, L., Estournel, C., Marsaleix, P., and Richard, E.: Dynamics of the North Balearic Front during an autumn tramontane and mistral storm: air-sea coupling processes and stratification budget diagnostic, Ocean Sci., 15, 179-198, https://doi.org/10.5194/os-15-179-2019, 2019.

Sodemann, H., Aemisegger, F., Pfahl, S., Bitter, M., Corsmeier, U., Feuerle, T., Graf, P., Hankers, R., Hsiao, G., Schulz, H., Wieser, A., and Wernli, H.: The stable isotopic composition of water vapour above Corsica during the HyMeX SOP1 campaign: insight into vertical mixing processes from lowertropospheric survey flights, Atmos. Chem. Phys., 17, 6125-6151, https://doi.org/10.5194/acp-17-6125-2017, 2017.

Stein, A. F., Draxler, R. R., Rolph, G. D., Stunder, B. J. B., Cohen, M. D., and Ngan, F.: NOAA's HYSPLIT Atmospheric Transport and Dispersion Modeling System, B. Am. Meteorol. Soc., 96, 2059-2077, https://doi.org/10.1175/bams-d-14-00110.1, 2015.

Stocchi, P. and Davolio, S.: Intense air-sea exchanges and heavy orographic precipitation over Italy: The role of Adriatic sea surface temperature uncertainty, Atmos. Res., 196, 62-82, https://doi.org/10.1016/j.atmosres.2017.06.004, 2017.

Strajnar, B., Cedilnik, J., Fettich, A., Ličer, M., Pristov, N., Smerkol, P., and Jerman, J.: Impact of two-way coupling and sea-surface temperature on precipitation forecasts in regional atmosphere and ocean models, Q. J. Roy. Meteor. Soc., 145, 228-242, https://doi.org/10.1002/qj.3425, 2019.

Strauss, C., Ricard, D., Lac, C., and Verrelle, A.: Evaluation of turbulence parametrizations in convective clouds and their environment based on a large-eddy simulation, Q. J. Roy. Meteor. Soc., 145, 3195-3217, https://doi.org/10.1002/qj.3614, 2019.

Taufour, M., Vié, B., Augros, C., Boudevillain, B., Delanoë, J., Delautier, G., Ducrocq, V., Lac, C., Pinty, J.-P., and Schwarzenböck, A.: Evaluation of the two-moment scheme LIMA based on microphysical observations from the HyMeX campaign, Q. J. Roy. Meteor. Soc., 144, 1398-1414, https://doi.org/10.1002/qj.3283, 2018.

Thévenot, O., Bouin, M.-N., Ducrocq, V., Brossier, C. L., Nuissier, O., Pianezze, J., and Duffourg, F.: Influence of the sea state on Mediterranean heavy precipitation: a case-study from HyMeX SOP1, Q. J. Roy. Meteor. Soc., 142, 377-389, https://doi.org/10.1002/qj.2660, 2015.

Tramblay, Y. and Somot, S.: Future evolution of extreme precipitation in the Mediterranean, Clim. Change, 151, 289-302, https://doi.org/10.1007/s10584-018-2300-5, 2018.

Turato, B., Reale, O., and Siccardi, F.: Water Vapor Sources of the October 2000 Piedmont Flood, J. Hydrometeorol., $\quad 5, \quad 693-712$, https://doi.org/10.1175/15257541(2004)005<0693:wvsoto>2.0.co;2, 2004.

Uber, M., Vandervaere, J.-P., Zin, I., Braud, I., Heistermann, M., Legoût, C., Molinié, G., and Nord, G.: How does initial soil moisture influence the hydrological response? A case study from southern France, Hydrol. Earth Syst. Sci., 22, 6127-6146, https://doi.org/10.5194/hess-22-6127-2018, 2018.

Varble, A., Fridlind, A. M., Zipser, E. J., Ackerman, A. S., Chaboureau, J.-P., Fan, J., Hill, A., McFarlane, S. A., Pinty, J.-
P., and Shipway, B.: Evaluation of cloud-resolving model intercomparison simulations using TWP-ICE observations: Precipitation and cloud structure, J. Geophys. Res., 116, D12206, https://doi.org/10.1029/2010jd015180, 2011.

Verrelle, A., Ricard, D., and Lac, C.: Sensitivity of high-resolution idealized simulations of thunderstorms to horizontal resolution and turbulence parametrization, Q. J. Roy. Meteor. Soc., 141, 433-448, https://doi.org/10.1002/qj.2363, 2014.

Verrelle, A., Ricard, D., and Lac, C.: Evaluation and Improvement of Turbulence Parameterization inside Deep Convective Clouds at Kilometer-Scale Resolution, Mon. Weather Rev., 145, 39473967, https://doi.org/10.1175/mwr-d-16-0404.1, 2017.

Vié, B., Molinié, G., Nuissier, O., Vincendon, B., Ducrocq, V., Bouttier, F., and Richard, E.: Hydro-meteorological evaluation of a convection-permitting ensemble prediction system for Mediterranean heavy precipitating events, Nat. Hazards Earth Syst. Sci., 12, 2631-2645, https://doi.org/10.5194/nhess12-2631-2012, 2012.

Vié, B., Pinty, J.-P., Berthet, S., and Leriche, M.: LIMA (v1.0): A quasi two-moment microphysical scheme driven by a multimodal population of cloud condensation and ice freezing nuclei, Geosci. Model Dev., 9, 567-586, https://doi.org/10.5194/gmd-9567-2016, 2016.

Vincendon, B., Ducrocq, V., Nuissier, O., and Vié, B.: Perturbation of convection-permitting NWP forecasts for flash-flood ensemble forecasting, Nat. Hazards Earth Syst. Sci., 11, 1529-1544, https://doi.org/10.5194/nhess-11-1529-2011, 2011.

Winschall, A., Pfahl, S., Sodemann, H., and Wernli, H.: Impact of North Atlantic evaporation hot spots on southern Alpine heavy precipitation events, Q. J. Roy. Meteor. Soc., 138, 1245-1258, https://doi.org/10.1002/qj.987, 2011.

Wu, F., Cui, X. and Zhang, D.-L.: A lightning-based nowcast-warning approach for short-duration rainfall events: Development and testing over Beijing during the warm seasons of 2006-2007, Atmos. Res., 205, 2-17, https://doi.org/10.1016/j.atmosres.2018.02.003, 2018.

Wyngaard, J. C. and Coté, O. R.: The Budgets of Turbulent Kinetic Energy and Temperature Variance in the Atmospheric Surface Layer, J. Atmos. Sci., 28, 190-201, https://doi.org/10.1175/15200469(1971)028<0190:tbotke>2.0.co;2, 1971.

Xie, S.-P., Xu, H., Kessler, W. S., and Nonaka, M.: Air-Sea Interaction over the Eastern Pacific Warm Pool: Gap Winds, Thermocline Dome, and Atmospheric Convection, J. Climate, 18, 5-20, https://doi.org/10.1175/jcli-3249.1, 2005.

Ziv, B., Saaroni, H., Romem, M., Heifetz, E., Harnik, N., and Baharad, A.: Analysis of conveyor belts in winter Mediterranean cyclones, Theor. Appl. Climatol., 99, 441-455, https://doi.org/10.1007/s00704-009-0150-9, 2009.

Zwiebel, J., Baelen, J. V., Anquetin, S., Pointin, Y., and Boudevillain, B.: Impacts of orography and rain intensity on rainfall structure. The case of the HyMeX IOP7a event, Q. J. Roy. Meteor. Soc., 142, 310-319, https://doi.org/10.1002/qj.2679, 2015. 